2016

\title{
Aboriginal Title and Indigenous Governance: Identifying the Holders of Rights and Authority
}

Kent McNeil

Osgoode Hall Law School of York University, kmcneil@osgoode.yorku.ca

Follow this and additional works at: http:// digitalcommons.osgoode.yorku.ca/olsrps

Part of the Indian and Aboriginal Law Commons

\section{Recommended Citation}

McNeil, Kent. "Aboriginal Title and Indigenous Governance: Identifying the Holders of Rights and Authority." Osgoode Legal Studies Research Paper Series, vol. 12, no. 14, 2016: 50.

This Article is brought to you for free and open access by the Research Papers, Working Papers, Conference Papers at Osgoode Digital Commons. It has been accepted for inclusion in Osgoode Legal Studies Research Paper Series by an authorized administrator of Osgoode Digital Commons. 
Osgoode Legal Studies Research Paper No. 67

Vol. 12/ Issue. 14/ (2016)

\title{
Aboriginal Title and Indigenous Governance: Identifying the Holders of Rights and Authority
}

\author{
Kent McNeil
}

\begin{abstract}
:
Aboriginal rights, including Aboriginal title to land, are communal rights that are vested in Indigenous collectivities that are connected to the specific Indigenous groups that occupied and used land prior to European colonization of Canada. Identifying the present-day collectivities that hold these rights is therefore essential. This research paper examines the jurisprudence on this matter in relation to three categories of court decisions: Aboriginal title cases, Aboriginal rights cases apart from title, and duty to consult cases. Analysis of the case law reveals that identification of current rights holders is treated as a matter of fact that depends in part on the laws of the Indigenous people concerned. Although the courts have generally avoided considering the implications of this for self-government, the author contends that Aboriginal rights necessarily entail governance authority that must likewise be vested in rights-holding collectivities.
\end{abstract}

Keywords:

Indigenous rights, Aboriginal title, Indigenous governance, Indigenous rights holders

\section{Author(s):}

Kent McNeil

Osgoode Hall Law School, York University

E: kmcneil@osgoode.yorku.ca 


\title{
Aboriginal Title and Indigenous Governance: Identifying the Holders of Rights and Authority
}

\author{
(C) Kent McNeil ${ }^{*}$
}

Research Paper, 31 May 2016

Section 35(1) of the Constitution Act, 1982, recognizes and affirms the "aboriginal and treaty rights of the aboriginal peoples of Canada". The Aboriginal peoples are defined in s.35(2) as including "the Indian, Inuit and Métis peoples of Canada." That is the extent to which the Canadian Constitution identifies the potential holders of s.35 rights, leaving the matter to be resolved by judicial decisions or negotiated agreements. This research paper examines how Canadian courts have addressed the issue of identifying Aboriginal rights holders in specific instances, mainly in parts of Canada that are not subject to historical or modern-day treaties relating to land. As the focus is on the law of the Canadian state as interpreted and applied by the courts, especially the Supreme Court of Canada, the analysis is doctrinal. Of course Indigenous peoples have their own legal orders, ${ }^{1}$ and I am of the

\footnotetext{
* Osgoode Hall Law School, Toronto. I am very grateful to Julia Drehuta and Margarita Malkina for their diligent and thorough research assistance, from which I benefited immensely in preparing this research paper. I would also like to thank the participants at the Conference on Determining Access: Theory and Practice in Implementing Indigenous Governance over Lands and Resources, Thompson Rivers University and the Interior Alliance, Kamloops, B.C., February 15-16, 2016, for valuable feedback on an oral presentation of this paper. Special thanks also are due to Chris Albinati, Julie Falck, Janna Promislow, Kathy Simo, and Kerry Wilkins for reading a draft and providing insightful comments.

${ }^{1}$ See e.g. Val Napoleon, “Tsilhqot'in Law of Consent” (2015) UBC L. Rev. 873 [Napoleon, “Tsilhqot'in Law"], and "Thinking About Indigenous Legal Orders”, National Centre for First Nations Governance Research Paper, 18 June 2007, online: http://fngovernance.org/ncfng_research/val_napoleon.pdf; Ardith Walkem, “An Unfulfilled Promise: Still Fighting to Make Space for Indigenous Legal Traditions”, in Maria Morellato, ed., Aboriginal Law Since Delgamuukw (Aurora, ON: Canada Law Book, 2009), 393; John Borrows, Canada's Indigenous Constitution (Toronto: University of Toronto Press, 2010). For discussion of the relevance of Indigenous norm generation to the issues discussed in this paper, and of broader theoretical and practical considerations, see Brent Olthuis, "The Constitution's Peoples: Approaching Community in the context of Section 35 of the Constitution Act, 1982” (2009) 54 McGill L.J. 1.
} 
view that identification of Aboriginal rights holders should involve the application of Indigenous law, derived from Indigenous governance authority. Canadian courts can, and occasionally do, take account of Indigenous law in rendering decisions, but they inevitably do so within the framework of the Canadian legal system from which they derive their authority, rather than within the context of Indigenous legal orders and governance authority. So when Indigenous people go to or end up in Canadian courts, either by choice or because they have been charged with an offence or sued in a civil action, they find themselves subject to the Canadian law that is applied by the courts. It is therefore essential for them to know how a Canadian court might address the matters at issue, which can include determining the identity of Aboriginal rights claimants.

In this paper, I am going to discuss three categories of decisions: (1) Aboriginal title cases; (2) Aboriginal rights cases apart from title; and (3) duty to consult cases. My focus is mainly on Supreme Court decisions involving First Nation Indigenous people arising in non-treaty areas. The issue of the identity of Aboriginal title and rights holders can also arise in cases involving the Inuit and the Métis, but there is a scarcity of case law on the issue where the Inuit are concerned, ${ }^{2}$ and the unique circumstances of the Métis and the current length of this paper led me to conclude that a separate research paper would be necessary for the issue of the identity of Métis rights holders to be dealt with adequately.

\section{Aboriginal Title Cases}

\footnotetext{
${ }^{2}$ For a rare exception, see Hamlet of Clyde River v. TGS-NOPEC Geophysical Co. ASA (TGS), 2015 FCA 179, 474 N.R. 96 [Hamlet of Clyde River], leave to appeal to the S.C.C. granted March 10, 2016.
} 
Five foundational Aboriginal title cases have reached the Supreme Court of Canada: ${ }^{3}$ Calder v. Attorney General of British Columbia ${ }^{4}$ Delgamuukw v. British Columbia; ${ }^{5}$ R. v. Marshall; $R$ v. Bernard; ${ }^{6}$ and Tsilhqot'in Nation v. British Columbia. ${ }^{7}$ While the matter of the appropriate title holders was not a live issue in Calder and Marshall/Bernard, these decisions are nonetheless relevant and important because they reveal underlying assumptions of the parties and the judges.

Calder was a representative action, brought by Frank Calder and other members of the Nisga'a Nation (referred to as the Nishga Nation and the Nishga Indian Tribe in the case) on behalf of that nation, seeking a

\footnotetext{
${ }^{3}$ Although Aboriginal title was discussed in St. Catherine's Milling and Lumber Company v. The Queen (1886), 13 S.C.R. 577, affirmed (1888) 14 App. Cas. 46 (P.C.), the case involved a dispute between the federal government and the Province of Ontario over entitlement to lands and resources after the Aboriginal title had been supposedly surrendered by Treaty 3 (1873). No Indigenous nations or persons were party to the action or even called as witnesses.

${ }^{4}$ [1973] S.C.R. 313 [Calder].

${ }^{5}$ [1997] 3 S.C.R. 1010 [Delgamuukw, SCC].

${ }^{6}$ R. v. Marshall and R. v. Bernard were heard together in the Supreme Court, resulting in a single judgment: [2005] 2 S.C.R. 220 [Marshall/Bernard].

${ }^{7}$ [2014] 2 S.C.R. 257 [Tsilhqot'in Nation, SCC]. In addition to these five Supreme Court decisions, see the decision of the British Columbia Court of Appeal in Oregon Jack Creek Indian Band v. Canadian National Railway, [1990] 2 C.N.L.R. 85 [Oregon Jack Creek Indian Band], affirmed in brief oral reasons, [1989] 2 S.C.R. 1069. This decision involved an application to amend a statement of claim, brought by 36 chiefs of Indian bands on behalf of themselves and all other members of their bands, alleging that double-tracking of a section of the CNR along the Thompson River would negatively affect Aboriginal title and fishing rights in the Thompson and Fraser rivers. In allowing the amendment of the representative action to include all members of the three Aboriginal nations whose ancestors had occupied lands along these rivers prior to European colonization, MacFarlane J.A., delivering the unanimous judgment, stated at page 92: "In my opinion, the date at which it must be shown that there was an organized society occupying the specific territory over which the plaintiffs, as descendants of the members of that society, now assert aboriginal title is the date at which sovereignty was asserted by the Europeans. The society need not have been what we now regard as a legal entity, and the descendants of that society need not, in order to have status to bring an action, prove that such a legal entity now exists. Whether the plaintiffs can establish the necessary criteria and show that they are descendants of the members of a society who in common held such aboriginal rights is a matter to be determined on evidence.” In a short judgment dismissing an application to rehear the appeal it had already rejected, the Supreme Court observed that, in pronouncing "that the action was personal in nature rather than derivative and the plaintiffs need not establish either the continued existence of the Indian nations nor authority to bring the action..., the Court of Appeal went beyond the narrow issue before them - whether the pleadings were clearly invalid", but the Court decided that those obiter pronouncements did not affect the outcome on that narrow issue and so did not provide grounds for a rehearing (the Supreme Court declined to comment on the correctness of the pronouncements): [1990] 1 S.C.R. 117 at para. 3. As far as I am aware, this case never went to trial. On the B.C.C.A. decision, see also Olthuis, above note 1 at 11-12.
} 
declaration "that the aboriginal title, otherwise known as the Indian title, of the Plaintiffs to their ancient tribal territory hereinbefore described, has never been lawfully extinguished." 8 The trial judge found that the plaintiffs, who were officers of the Nishga Tribal Council and councilors of the four Indian Act bands into which the Nisga’a Nation had been divided, were "appropriate and adequate representatives to bring the action on the part of the Nishga Indian Tribe”. ${ }^{9}$ They were described by Justice Judson of the Supreme Court of Canada as "descendants of the Indians who have inhabited since time immemorial the territory in question". ${ }^{10}$ No one, including the plaintiffs who were members of the Nisga'a band councils, seems to have questioned that, if Aboriginal title existed, it was held by the Nisga'a Nation as a whole, not by the Indian bands or other subgroups within the nation. However, the consequences of the nation holding title were not addressed, as the Supreme Court refused the declaration because a majority of the judges decided that the action could not be brought against the Crown in right of British Columbia without a fiat (basically, permission) of the Lieutenant Governor of the province. ${ }^{11}$

Marshall/Bernard involved prosecutions under provincial statutes in Nova Scotia and New Brunswick for harvesting and possessing logs on lands the provinces claimed as Crown lands. The accused, who are members of the Mi'kmaq Nation in Nova Scotia and the Miramichi Mi'kmaq in New Brunswick, raised Aboriginal title, as well as treaty rights, as their defence. There seems to have been no question that they are Mi’kmaqs who would be

\footnotetext{
${ }^{8}$ Calder, above note 4 at 345, quoting from the statement of claim.

${ }^{9}$ Calder v. Attorney General of British Columbia (1969), 8 D.L.R. (3d) 59 at 61 (B.C.S.C.).

${ }^{10}$ Calder, above note 4 at 317.

${ }^{11}$ In his dissent, concurred in by Spence and Laskin JJ., Hall J. would have simply issued a declaration that "the appellants' right to possession ... and their right to enjoy the fruits of the soil, of the forest, and of the rivers and streams within the boundaries of said lands have not been extinguished”: ibid. at 422 .
} 
entitled to the benefits of Aboriginal title if they were able to establish that the Mi'kmaq had Aboriginal title to the sites where the cutting of timber took place. However, as the Supreme Court agreed with the trial judges that the accused had not proven that the Mi'kmaq exclusively occupied the sites at the time of the British Crown's assertion of sovereignty, their claim to Aboriginal title failed. Since they were also unable to convince the judges that they had treaty rights to harvest timber commercially, they were convicted.

In his trial judgment in $R$. v. Bernard, ${ }^{12}$ Justice Lordon seems to have taken for granted that the Miramichi Mi’kmaq, rather than the three Mi'kmaq bands with reserves in the area of New Brunswick where title was asserted, would be the Aboriginal title holders if title had been proven, which he decided it had not. On appeal, the New Brunswick Court of Appeal decided that the Miramichi Mi'kmaq do have collective Aboriginal title to the Northwest Miramichi watershed, ${ }^{13}$ but this decision was overturned by the Supreme Court.

In $R$. $v$. Marshall, ${ }^{14}$ the accused asserted that the Mi'kmaq had Aboriginal title to all of Nova Scotia. Justice Curran at trial accepted that they had lived in individual communities that got together on occasions, concluding that, although "they did not have a fully-developed sense of being a nation..., [t]hey were still a collection of communities." ${ }^{15}$ However, as he found that Aboriginal title had not been proven, the significance of this finding for the identity of the putative title holders was not discussed. The Nova Scotia Court of Appeal ordered a new trial because, among other

\footnotetext{
${ }^{12}$ [2000] 3 C.N.L.R. 184 (N.B. Prov. Ct.).

${ }^{13}$ R. v. Bernard, 2003 NBCA 55, [2003] 4 C.N.L.R. 48 at paras.190 (Daigle J.A.), 309-10 (Robertson J.A.).

${ }^{14} 2001$ NSPC 2, [2001] 2 C.N.L.R. 256 (N.S. Prov. Ct.) at para. 3 [Marshall, Prov. Ct.].

${ }^{15}$ Ibid. at para. 55.
} 
reasons, it held that Justice Curran, and the Summary Conviction Appeal Court that upheld his decision, ${ }^{16}$ had applied the wrong test for assessing the occupation required to establish Aboriginal title. ${ }^{17}$ Cromwell J.A. (since appointed to the Supreme Court of Canada) reviewed the trial judge's findings of fact on the Mi'kmaq social and political organization, territoriality, and land tenure and use, and seems to have accepted that the divisions of their territory in Nova Scotia into seven districts and family hunting territories were developments that came after the British Crown's assertion of sovereignty. ${ }^{18}$ As the trial judge had found that there was "no persuasive evidence that they divided the entire territory among their communities” prior to sovereignty, ${ }^{19}$ Cromwell J.A. apparently thought that their Aboriginal title, if proven, would be held by the Mi'kmaq people of Nova Scotia as a whole.

On appeal of the Marshall and Bernard cases to the Supreme Court, Chief Justice McLachlin stated the central issue to be whether "the Mi’kmaq people in Nova Scotia and New Brunswick ... have treaty rights or Aboriginal title entitling them" to "engage in commercial logging on Crown lands without authorization”. ${ }^{20}$ Throughout her judgment, she referred to the "Mi'kmaq" and "Mi'kmaq people” as the Aboriginal title claimants, without separating them into individual communities or bands. This is consistent

\footnotetext{
${ }^{16} 2002$ NSSC 57, [2002] 3 C.N.L.R. 176.

${ }^{17}$ [2004] 1 C.N.L.R. 211, especially at paras. 249-53 (Cromwell J.A.) [Marshall, CA]. Oland J.A. concurred with Cromwell J.A., and Saunders J.A. also agreed with his reasons and disposition on the title issue.

${ }^{18} \mathrm{Ibid}$. at paras. $141-52$.

${ }^{19}$ Marshall, Prov. Ct., above note 14 at para. 131, quoted and emphasized by Cromwell J.A., Marshall, CA, above note 17 at para. 151.

${ }^{20}$ Marshall/Bernard, above note 6 at para. 1. Note that, in my respectful opinion, the way McLachlin C.J.C. framed this issue begged the question of whether lands subject to Aboriginal title really are Crown lands: see Kent McNeil, “Aboriginal Title and the Supreme Court: What’s Happening?” (2006) 69 Sask. L. Rev. 281 at 293-96. However, in Tsilhqot'in Nation, SCC, above note 7 at para. 70, she returned to this issue and clarified that the Crown's underlying title to Aboriginal title lands does not have any beneficial content.
} 
with how the constitutional questions were stated in each case, asking whether the provincial legislation under which the accused had been charged is “inconsistent with Mi'kmaq Aboriginal title". ${ }^{21}$

The issue of the appropriate claimants in Aboriginal title cases was addressed more directly in Delgamuukw v. British Columbia. Unlike Marshall/Bernard, where Aboriginal title was raised as a defence to prosecutions, Delgamuukw involved a direct claim by the Gitksan and Wet'suwet'en peoples for a declaration of their Aboriginal title. It was a representative action, brought by "39 hereditary Gitksan and 12 Wet'suwet'en (total 51) chiefs for all or most of the Houses of the Gitksan and Wet'suwet'en peoples, except ... the 12 Kitwancool chiefs.”22 The position advanced by the plaintiffs at trial, as expressed by Chief Justice McEachern, was "that their chiefs are themselves, as well as on behalf of Houses or members, entitled to a judgment declaring their ownership, under Canadian, Gitksan and Wet'suwet'en law of the individual territories they claim. There is no specific alternative claim pleaded by the plaintiffs collectively for the territory or any part of it on a communal, people-wide basis.” ${ }^{23}$ As is well known, McEachern C.J.S.C. dismissed their claims, leading to appeals to the British Columbia Court of Appeal and then to the Supreme Court of Canada.

The Supreme Court overturned McEachern C.J.S.C.’s judgment and ordered a new trial, partly because of his treatment of the oral histories, but also because the plaintiffs had reframed the nature of the claim before the

\footnotetext{
${ }^{21}$ Marshall/Bernard, above note 6 at paras. 107-8.

${ }^{22}$ Delgamuukw v. British Columbia (1991), 79 D.L.R. (4 $\left.{ }^{\text {th }}\right) 185$ (B.C.S.C.) at 237 [Delgamuukw, BCSC]. For a list of the plaintiffs, see the style of cause in Delgamuukw, SCC, above note 5. Note that there are Gitksan and Wet'suwet'en band councils as well under the Indian Act, R.S.C. 1985, c. I-5, and the GitksanWet'suwet'en Tribal Council was formed in 1978, but while the latter played a coordinating role in the court case, it was not a plaintiff claiming title: Delgamuukw, BCSC, at 234-37.

${ }^{23}$ Delgamuukw, BCSC, above note 22 at 237.
} 
Supreme Court. Chief Justice Lamer explained that, on appeal, "the individual claims by each house have been amalgamated into two communal claims, one advanced on behalf of each nation. However, there were no formal amendments to the pleadings to this effect." ${ }^{24}$ He found this to be problematic:

Given the absence of an amendment to the pleadings, I must reluctantly conclude that the respondents [British Columbia and Canada] suffered some prejudice. The appellants [the Gitksan and Wet'suwet'en] argue that the respondents did not experience prejudice since the collective and individual claims are related to the extent that the territory claimed by each nation is merely the sum of the individual claims of each House; the external boundaries of the collective claims therefore represent the outer boundaries of the outer territories. Although that argument carries considerable weight, it does not address the basic point that the collective claims were simply not in issue at trial. To frame the case in a different manner on appeal would retroactively deny the respondents the opportunity to know the appellants' case. ${ }^{25}$

Although the defect in the pleadings, combined with the mistreatment of the oral histories, prevented the Court from deciding the case on its merits, Lamer C.J.C. nonetheless proceeded to provide guidelines to trial courts on a number of vital issues, including proof, content, infringement, and extinguishment of Aboriginal title. For the purposes of this research paper, the most relevant aspect of his judgment is his apparent acceptance throughout that, if the case had been properly pleaded, Aboriginal title would be held by Aboriginal nations rather than by smaller collectives within nations, such as the Gitksan and Wet'suwet'en houses. In a particularly relevant passage, he stated:

\footnotetext{
${ }^{24}$ Delgamuukw, SCC, above note 5 at para. 73. British Columbia and Canada argued that they were prejudiced as a result: ibid.

${ }^{25} \mathrm{Ibid}$. at para. 76.
} 
A further dimension of Aboriginal title is the fact that it is held communally. Aboriginal title cannot be held by individual Aboriginal persons; it is a collective right to land held by all members of an Aboriginal nation. Decisions with respect to that land are also made by that community. This is another feature of aboriginal title which is sui generis and distinguishes it from normal property interests. ${ }^{26}$

This should not be interpreted to mean that the rights and interests of houses, clans, and other smaller groups are unimportant or lack legal validity. Instead, I understand it to mean that Aboriginal title is a territorial right vested in the whole nation that applies externally as against the Crown and other persons who are not members of that nation. ${ }^{27}$ It is what my colleague Brian Slattery has referred to as a generic right because, apart perhaps from its inherent limit that does not allow the land to be used in ways that substantially diminish its value for future generations, ${ }^{28}$ it does not vary from one Aboriginal nation to another. ${ }^{29}$ It provides common law - and, since 1982, constitutional - protection to Indigenous territories within Canada. ${ }^{30}$ Internally, houses, clans, families, individuals, and so on continue

\footnotetext{
${ }^{26}$ Ibid. at para. 115 [emphasis added].

${ }^{27}$ For further discussion, see Kent McNeil, “Aboriginal Title in Canada: Site-Specific or Territorial?” (2012) 91 Can. Bar Rev. 745.

${ }^{28}$ See Delgamuukw, SCC, above note 5 at paras. 125-32; Tsilhqot'in Nation, SCC, above note 7 at paras. 74, 88. Note that McLachlin C.J.C. in the latter case reformulated the inherent limit from a backwardlooking limit determined by historical uses to a forward-looking approach emphasizing sustainability: see Brian Slattery, "The Constitutional Dimensions of Aboriginal Title” (2015) 71 Supreme Court L. Rev. (2d) 45 at 58-63 [Slattery, "Constitutional Dimensions"]; Kent McNeil, "Aboriginal Title and the Provinces after Tsilhqot'in Nation” (2015) 71 Supreme Court L. Rev. (2d) 67 at 68 [McNeil, “Aboriginal Title and the Provinces"]. Query whether this reformulation makes the inherent limit more uniform among Aboriginal title holders.

${ }^{29}$ Brian Slattery, “Understanding Aboriginal Rights” (1987) 66 Can. Bar Rev. 727 at 745 [Slattery, "Understanding Aboriginal Rights"], and "The Metamorphosis of Aboriginal Title” (2006) 85 Can. Bar Rev. 255 at 269-71 [Slattery, "Metamorphosis"], both quoted with approval by Vickers J. in his trial judgment in Tsilhqot'in Nation v. British Columbia, 2007 BCSC 1700, [2008] 1 C.N.L.R. 112 at paras. 471-72 (B.C.S.C.) [Tsilhqot'in Nation, BCSC], and also cited with apparent approval by Groberman J.A. in his judgment on appeal in the same case, subnom. William v. British Columbia, 2012 BCCA 285, [2012] 3 C.N.L.R. 333 at para. 149 (B.C.C.A.) [Tsilhqot'in Nation, BCCA].

${ }^{30}$ See Kent McNeil, “Aboriginal Title as a Constitutionally Protected Property Right”, in Owen Lippert, ed., Beyond the Nass Valley: National Implications of the Supreme Court's Delgamuukw Decision
} 
to have rights under a nation's Indigenous laws, ${ }^{31}$ which are subject to the territorial authority of the nation and so should be alterable through the exercise of its inherent right of self-government. ${ }^{32}$

The more recent case of Tsilhqot'in Nation v. British Columbia is the strongest precedent so far on the identity of Aboriginal title holders, given that this was a contentious issue that was dealt with in some depth both at trial and in the Court of Appeal. Like Delgamuukw, this was a representative action for a declaration of Aboriginal title and other Aboriginal rights, brought by Chief Roger William "on his own behalf and on behalf of all other members of the Xeni Gwet'in First Nations Government and on behalf of all other members of the Tsilhqot'in Nation”. 33 The Xeni Gwet'in, of which Roger Williams is chief, is one of the six Indian Act bands that make up the Tsilhqot'in Nation. The plaintiff and Canada (a defendant in the case, but supporting the plaintiff's position on this issue) contended that the community of Tsilhqot'in people is the holder of the title and other

(Vancouver: The Fraser Institute, 2000), 55, republished in Kent McNeil, Emerging Justice? Essays on Indigenous Rights in Canada and Australia (Saskatoon: University of Saskatchewan Native Law Centre, 2001), 292; McNeil, “Aboriginal Title and the Provinces”, above note 28.

${ }^{31}$ See Behn v. Moulton Contracting Ltd., [2013] 2 S.C.R. 227 at paras. 30-31[Behn], quoted in text accompanying notes 108-9 below.

${ }^{32}$ See Slattery, "Metamorphosis", above note 29 at 270, and "Constitutional Dimensions", above note 28 at 52-54; Jeremy Webber, “The Public Law Dimension of Indigenous Property Rights”, in Nigel Bankes and Timo Koivurova, eds., The Proposed Nordic Saami Convention: National and International Dimensions of Indigenous Property Rights (Oxford: Hart Publishing, 2013), 79; Kent McNeil, "Exclusive Occupation and Joint Aboriginal Title” (2015) 48 UBC L. Rev. 821 at 870-71 [McNeil, “Joint Aboriginal Title”]. Aboriginal nations' inherent right of self-government over their Aboriginal title lands was acknowledged by Williamson J. in Campbell v. British Columbia, [2000] 4 C.N.L.R. 1 (B.C.S.C.) [Campbell v. B.C.]: see discussion in Kent McNeil, "Judicial Approaches to Self-Government since Calder: Searching for Doctrinal Coherence”, in Hamar Foster, Heather Raven, and Jeremy Webber, eds., Let Right Be Done: Aboriginal Title, the Calder Case, and the Future of Indigenous Rights (Vancouver: UBC Press, 2007), 129 at 139-43. In House of Sga'nisim v. Canada (Attorney General), [2012] 2 C.N.L.R. 82 (B.C.S.C.), Smith J. followed Campbell v. B.C. out of comity, but also held that the governance provisions of the Nisga'a Final Agreement, 1998, the validity of which were challenged in these cases, could be upheld as delegated governmental authority. Smith J.'s decision was affirmed on appeal on the latter basis, without deciding the inherent right issue: 2013 BCCA 49, [2013] 2 C.N.L.R. 226, leave to appeal refused, [2013] S.C.C.A. No. 44. For commentary, see Joshua Nichols, "A Reconciliation without Recollection? Chief Mountain and the Sources of Sovereignty” (2015) 48 UBC L. Rev. 515.

${ }^{33}$ Tsilhqot'in Nation, BCSC, above note 29, style of cause. 
Aboriginal rights, whereas British Columbia argued at trial, and again in the British Columbia Court of Appeal, that the title and rights holder is the Xeni Gwet'in people. $^{34}$ The trial judge, Justice Vickers, reviewed the limited Supreme Court of Canada jurisprudence on this issue (especially Calder, Delgamuukw, Marshall/Bernard, and the Métis Aboriginal rights case, $R$. $v$. Powley ${ }^{35}$ ), and observed:

No matter how a contemporary community defines membership, a critical inquiry for the purposes of s.35(1) rights is an ancestral connection to the relevant community extant at contact in the case of rights, or at sovereignty, in the case of title. In all of the Aboriginal rights and title decisions I have reviewed, the relevant historic community has been the larger First Nation that existed at the time of contact or sovereignty. ${ }^{36}$

This raises the issue of continuity between the Aboriginal nation in whom title vested at the time of Crown assertion of sovereignty ${ }^{37}$ and the present title-holding collective. In Marshall/Bernard, McLachlin C.J.C. put it this way: "The requirement of continuity in its most basic sense simply means that claimants must establish they are right holders. Modern-day claimants must establish a connection with the pre-sovereignty group upon whose practices they rely to assert title or claim to a more restricted aboriginal right." 38 However, although there must be an ancestral connection

\footnotetext{
${ }^{34}$ Ibid. at para. 437. One reason why British Columbia contended that title is held by the band rather than the nation as a whole was practical: to fulfil its duty to consult, the province argued that it needs to be able to engage with a definable legal entity, and the evidence revealed that the Tsilhqot'in Nation as a whole lacked a national political structure. See Tsilhqot'in Nation, BCCA, above note 29 at paras. 138-43. But the province also raised a jurisprudential issue: see text accompanying notes $45-47$ below.

${ }^{35}$ [2003] 2 S.C.R. 207 [Powley].

${ }^{36}$ Tsilhqot'in Nation, BCSC, above note 29 at para. 445.

${ }^{37}$ See Delgamuukw, SCC, above note 5 at para. 145, per Lamer C.J.C.: "Aboriginal title crystallized at the time sovereignty was asserted.” For discussion in light of Tsilhqot'in Nation, SCC, above note 7, see McNeil, “Aboriginal Title and the Provinces”, above note 28 at 71-78.

${ }^{38}$ Marshall/Bernard, above note 6 at para. 67. See also the quotation from Oregon Jack Creek Indian Band in note 7 above. Note that this is only one way in which the concept of continuity applies in the context of Aboriginal rights. As McLachlin C.J.C. went on to say in Marshall/Bernard, it can also mean that there must be a sufficient similarity or connection between the historical practice on which an Aboriginal right is
} 
by descent or succession between the Aboriginal people who were in exclusive occupation at the time of Crown sovereignty and the current claimants, $^{39}$ this does not mean that they need be socially or politically organized in the same way. ${ }^{40}$

Returning to Vickers J.'s judgment, on this issue he concluded: [T]he proper rights holder, whether for Aboriginal title or Aboriginal rights, is the community of Tsilhqot'in people. Tsilhqot'in people were the historic community of people sharing language, customs, traditions, historical experience, territory and resources at the time of first contact and at sovereignty assertion. The Aboriginal rights of individual Tsilhqot'in people or any other sub-group within the Tsilhqot'in Nation are derived from the collective actions, shared language, traditions and shared historical experiences of the members of the Tsilhqot'in Nation. ${ }^{41}$

Regarding British Columbia's argument that Tsilhqot'in bands are the proper holders of Aboriginal rights and title today, Vickers J. observed:

The setting aside of reserves and the establishment of bands was a convenience to government at both levels. The creation

based and the exercise of the right in the present. See also R. v. Van der Peet, [1996] 2 S.C.R. 507 at paras. 60-65 [Van der Peet]; Lax Kw'alaams Indian Band v. Canada (Attorney General), [2011] 3 S.C.R. 535 at paras. 48-59 [Lax Kw'alaams]. When present occupation of land is relied upon to raise an inference of occupation at the time of Crown assertion of sovereignty for the purpose of establishing Aboriginal title, there must also be continuity between the present-day and historical occupation: see Delgamuukw, SCC, above note 5 at paras. 152-54; Tsilhqot'in Nation, SCC, above note 7 at paras. 45-46. For more detailed discussion, see Kent McNeil, “Continuity of Aboriginal Rights”, in Kerry Wilkins, ed., Advancing Aboriginal Claims: Visions/Strategies/Directions (Saskatoon: Purich Publishing, 2004), 127.

${ }^{39}$ See also La Forest J.'s concurring judgment in Delgamuukw, SCC, above note 5 at para. 198, where he suggested that "the presence of two or more aboriginal groups in a territory may also have an impact on continuity of use. For instance, one aboriginal group may have ceded its possession to subsequent occupants or merged its territory with that of another aboriginal society. As well, the occupancy of one aboriginal society may be connected to the occupancy of another society by conquest or exchange. In these circumstances, continuity of use and occupation, extending back to the relevant time, may very well be established."

${ }^{40}$ See Tsilhqot'in Nation, BCSC, above note 29 at para. 457: "The political structures may change from time to time. Self identification may shift from band identification to cultural identification depending on the circumstances. What remains constant are the common threads of language, customs, traditions and a shared history that form the central 'self' of a Tsilhqot'in person. The Tsilhqot'in Nation is the community with whom Tsilhqot'in people are connected by those four threads.”

${ }^{41}$ Ibid. at para. 470. 
of bands did not alter the true identity of the people. Their true identity lies in their Tsilhqot'in lineage, their shared language, customs, traditions and historical experiences. While band level organization may have meaning to a Canadian federal bureaucracy, it is without any meaning in the resolution of Aboriginal title and rights for Tsilhqot'in people. ${ }^{42}$

Although the Xeni Gwet'in people are regarded by the Tsilhqot'in as the caretakers of the lands in the Claim Area (which consists of only about 5\% of the Tsilhqot'in's claimed traditional territory ${ }^{43}$ ), Vickers J. observed that "the caretakers have no more rights to the land or the resources than any other Tsilhqot'in person." 44 So the subgroup responsible for the land is not necessarily the holder of title thereto and other Aboriginal rights.

In the Court of Appeal, Justice Vickers' decision on this issue was challenged by British Columbia. The province argued that the Xeni Gwet'in band was the proper title and rights holder because the "historical and ethnographic evidence ... established that decision-making typically took place at the encampment or band level, and that while there were local chiefs, the Tsilhqot'in did not have a national chief or political organization." 45 Given these facts, the province contended that "the absence of any traditional pan-Tsilhqot'in governance structure is fatal to any claim on behalf of the Tsilhqot'in Nation."46 Justice Groberman, writing the unanimous judgment of the Court of Appeal, responded to this argument as follows:

\footnotetext{
42 Ibid. at para. 469.

${ }^{43}$ See Tsilhqot'in Nation, SCC, above note 7 at para. 6.

${ }^{44}$ Tsilhqot'in Nation, BCSC, above note 29 at para. 468. See also para. 459.

${ }^{45}$ Tsilhqot'in Nation, BCCA , above note 29 at para. 53.

${ }^{46}$ Ibid. at para. 145. Interestingly, by making this argument British Columbia implicitly acknowledged that there is an intimate connection between Aboriginal title and governance. On this, see note 32 above and text accompanying notes 168-75 below.
} 
If the law adopted such a position, it might well be devastating to claims by groups such as the Tsilhqot'in. The judge found that Tsilhqot'in decision-making and governance traditionally took place on a localized level, typically within family or encampment groupings, depending on the season. Because of the fluidity of the group structure and the limits of available evidence, however, it would be impossible to trace those localized collectives into modern counterparts. If Aboriginal rights devolve only upon collectives that can show that they are the modern successors of groups that had a clear decisionmaking structure, no one would be able to claim Aboriginal rights on behalf of the Tsilhqot'in. ${ }^{47}$

Although Vickers J. had concluded that the Tsilhqot'in did not have a national political structure, either historically or at the time of the trial, ${ }^{48}$ Groberman J.A. did not regard this as an impediment to finding that Aboriginal title and rights are held by the Tsilhqot'in people as a whole. While acknowledging the practical difficulties faced by the province in fulfilling its duty to consult if Aboriginal title and rights are held by a nation that lacks a national political structure with decision-making authority, he agreed with Vickers J. that "the evidence clearly established that the holders of Aboriginal rights within the Claim Area have traditionally defined themselves as being the collective of all Tsilhqot'in people. The Tsilhqot'in Nation, therefore, is the proper rights holder."49 Commenting further on British Columbia's arguments on this issue, Groberman J.A. observed:

In my view, the position taken by British Columbia does not take adequate account of the Aboriginal perspective with respect to this matter. I agree with the trial judge's conclusion that the definition of the proper rights holder is a matter to be

\footnotetext{
${ }^{47}$ Ibid. at para. 146.

${ }^{48}$ See Tsilhqot'in Nation, BCSC, above note 29 at para. 456; Tsilhqot'in Nation, BCCA, above note 29 at paras. 55, 140.

${ }^{49}$ Tsilhqot'in Nation, BCCA, above note 29 at para. 150.
} 
determined primarily from the viewpoint of the Aboriginal collective itself. ${ }^{50}$

Regarding the practical problem facing governments that have a legal obligation to consult with Indigenous peoples who have claimed or established Aboriginal title and rights, Groberman J.A. found that, "[f]ortunately, the record in this case resolves the question of who speaks for the Tsilhqot'in Nation” in relation to particular lands within their traditional territory, specifically the Claim Area. ${ }^{51}$ As the evidence showed that the Xeni Gwet'in are the custodians or caretakers of that area, "they have a special role in asserting those rights and in engaging with governments in attempts to reconcile them with broader public interests."52

The decision of the Court of Appeal in Tsilhqot'in Nation was appealed to the Supreme Court, which overturned Groberman J.A's ruling that Aboriginal title had not been proven and, for the first time in Canada, issued a declaration of Aboriginal title. ${ }^{53}$ At the Supreme Court, British Columbia apparently abandoned its contention - or at least did not argue the point - that Aboriginal title and other rights are held by Indian Act bands rather than nations. ${ }^{54}$ The decisions of Vickers J. and Groberman J.A. on this

\footnotetext{
${ }^{50}$ Ibid. at para. 149.

${ }^{51}$ Ibid. at para.152.

52 Ibid. at para. 156.

53 Tsilhqot'in Nation, SCC, above note 7. For collections of articles discussing the decision, see Special Issue: Tsilhqot'in Nation v British Columbia (2015) 48:3 UBC L. Rev. 693-970; (2015) 71 Supreme Court L. Rev. $\left(2^{\text {nd }}\right)$ 27-134.

${ }^{54}$ This issue was not raised in the Factum of the Province of British Columbia submitted to the Supreme Court, online: http://www.scc-csc.ca/WebDocuments-DocumentsWeb/34986/FM020_Respondents_HerMajesty-the-Queen-et-al.pdf. On the contrary, the province seems to have accepted Groberman J.A.’s decision on this point, observing that, in his reasons, "[t]he Aboriginal perspective was at the forefront of the recognition of the Tsilhqot'in as the collective that is the proper holder of Aboriginal rights”: ibid. at para. 151.
} 
issue can therefore be taken as affirmed by the Supreme Court's declaration of title in favour of the Tsilhqot'in Nation as a whole. ${ }^{55}$

The Supreme Court's declaration of the Tsilhqot'in's title raises an interesting legal personality issue. ${ }^{56}$ The Court held in Delgamuukw, ${ }^{57}$ and affirmed in Tsilhqot'in Nation, ${ }^{58}$ that Aboriginal title is a proprietary right. In the common law, only natural persons (living human beings) and artificial persons (corporations) have the legal personality necessary to hold property rights. ${ }^{59}$ For this reason, unless provided with this capacity expressly or implicitly by statute, collections of individuals, such as clubs and other unincorporated associations, generally cannot own property in their own right; instead, title is vested in all the members for the time being. ${ }^{60}$ It seems clear from the cases we have already examined that Aboriginal title is not vested in all the members of an Aboriginal nation as individuals; instead, it is a

\footnotetext{
${ }^{55}$ Tsilhqot'in Nation, SCC, above note 7 at para. 93: "with the declaration of title, the Tsilhqot'in have now established Aboriginal title" [emphasis added]. See also Kwicksutaineuk/Ah-Kwa-Mish First Nation v. Canada (Attorney General), [2012] 3 C.N.L.R. 148 (B.C.C.A.) [Kwicksutaineuk/Ah-Kwa-Mish First Nation], especially at para. 77, deciding that Indian Act bands are not necessarily the proper entities to be certified in a class action alleging infringement of Aboriginal fishing rights by fish farming in the Broughton Archipelago. In a concurring judgment, Smith J.A. stated at para. 104: "While Aboriginal fishing rights adhere to the Aboriginal entity asserting them, they are not personal rights of the individual members of the Aboriginal entity; they do not exist independent of the entity. Rather they are collective rights that are for the use and benefit of all of the members of the Aboriginal entity asserting them."

${ }^{56}$ For further discussion, see "The Post-Delgamuukw Nature and Content of Aboriginal Title", in Kent McNeil, Emerging Justice? Essays on Indigenous Rights in Canada and Australia (Saskatoon: University of Saskatchewan Native Law Centre, 2001), 102 at 122-27 [McNeil, "Post-Delgamuukw"].

${ }^{57}$ Delgamuukw, SCC, above note 5 at para. 113.

${ }^{58}$ Tsilhqot'in Nation, SCC, above note 7 at paras. 67-76, especially at para. 72 ("Analogies to other forms of property ownership - for example, fee simple - may help us to understand aspects of Aboriginal title") and para. 73 ("Aboriginal title confers ownership rights similar to those associated with fee simple") [emphasis added].

${ }^{59}$ Even the Crown is regarded as a corporation for this purpose: see F.W. Maitland, "The Crown as Corporation Sole" (1901) 17 L.Q. Rev. 131.

${ }^{60}$ See generally Dennis Lloyd, The Law Relating to Unincorporated Associations (London: Sweet and Maxwell Ltd., 1938); Harold A.J. Ford, Unincorporated Non-Profit Associations: Their Property and Their Liability (Oxford: Clarendon Press, 1959); S.J. Stoljar, Groups and Entities: An Enquiry into Corporate Theory (Canberra: Australian National University Press, 1973). Note that another option is for the legal title to be held by a trustee for the benefit of the members, but in that situation the members still hold the equitable title as individuals, not as a collective with legal personality.
} 
communal right vested in the whole nation as a single legal entity. ${ }^{61}$ In other words, apart from those Aboriginal nations that have been accorded the capacity to hold property rights by statute and land claims agreements, ${ }^{62}$ Aboriginal nations that have Aboriginal title must, at common law, have the legal personality necessary to have property rights. ${ }^{63}$ Moreover, as these nations have communal decision-making authority over their lands, Aboriginal title is not just proprietary - it is also governmental in nature. ${ }^{64}$ As Brian Slattery has recently argued, this means that it is more akin to unencumbered provincial title to land than it is to private real property rights. ${ }^{65}$

In summary, I think it is clear from the cases we have discussed that Aboriginal title is held by Aboriginal nations or polities that are the descendants or successors of the Aboriginal peoples that were in exclusive occupation of their traditional territories at the time of Crown assertion of sovereignty. ${ }^{66}$ This is consistent with the jurisprudence on Aboriginal rights

\footnotetext{
${ }^{61}$ See the quotation from Delgamuukw, SCC, accompanying note 26 above.

${ }^{62}$ E.g. see the Nisga'a Final Agreement, initialled 4 August 1998, online: http://www.nnkn.ca/files/u28/niseng.pdf, ch. 11, s.5,: “The Nisga'a Nation, and each Nisga'a Village, is a separate and distinct legal entity, with the capacity, rights, powers, and privileges of a natural person, including to ... acquire and hold property or an interest in property, and sell or otherwise dispose of that property or interest.” ${ }^{63}$ Compare Kwicksutaineuk/Ah-Kwa-Mish First Nation, above note 55, where Garson J.A. stated at para. 79: "Because the term 'aboriginal collective' is not defined in the order or in the reasons for judgment, the question is whether such a group is a juridical person. As addressed above, the respondent argues that because the Aboriginal collectives hold constitutional rights, they ought to be able to sue through this class action. I decline to decide in a general way if any Aboriginal collective, for example a First Nation that may be organized and governed along traditional lines, could or could not be a juridical person. That question can be left for another day." However, in this case the "Aboriginal collective” having or asserting Aboriginal fishing rights was not sufficiently identified and defined, and that is why the Court of Appeal decided it did not comprise a sufficiently precise class for the purposes of certification.

${ }^{64}$ See note 32 above and accompanying text. See also Kent McNeil, "Indigenous Land Rights and SelfGovernment: Inseparable Entitlements”, in Lisa Ford and Tim Rowse, eds., Between Indigenous and Settler Governance (Abingdon, U.K.: Routledge, 2013), 135; Andrée Boisselle, "To Dignity Through the Back Door: Tsilhqot'in and the Aboriginal Title Test” (2015) 71 Supreme Court L. Rev. $\left(2^{\text {nd }}\right)$ 27; Gordon Christie, “Who Makes Decisions over Aboriginal Title Lands?” (2015) 48 UBC L. Rev. 743.

${ }^{65}$ Slattery, "Constitutional Dimensions", above note 28. See also McNeil, "Post-Delgamuukw”, above note 56 at 124-25; Webber, above note 32.

${ }^{66}$ The same basic conclusion was reached by Royal Commission on Aboriginal Peoples regarding entitlement to the right of self-determination: see Report of the Royal Commission on Aboriginal Peoples (Ottawa: Minister of Supply and Services Canada, 1996), vol. 2, Restructuring the Relationship, part 1, 177-80. Compare West Moberley First Nations v. McLeod Lake Indian Band, 2014 BCCA 283, 62
} 
apart from title that we will now examine. In examining these cases, it is nonetheless important to keep in mind a fundamental distinction between Aboriginal title and other Aboriginal rights. Aboriginal title is exclusive, so except in situations where two or more Aboriginal nations share joint title, ${ }^{67}$ only one nation can have title to any particular land. ${ }^{68}$ As exclusivity does not appear to be a requirement for establishing other Aboriginal rights, proof that one Aboriginal nation or polity has an Aboriginal right - to hunt or fish in a particular place, for example - should not bar other Aboriginal groups from establishing that they have such a right as well. ${ }^{69}$

\section{Aboriginal Rights Cases $^{70}$}

In many of the cases involving Aboriginal rights apart from title, at least those that have reached the Supreme Court of Canada, the identity of the rights holding entity does not appear to have been an issue. Most of these

B.C.L.R. (5th) 303, where the B.C. Court of Appeal upheld an order granting intervenor status to two Indian Act bands (the Takla Lake First Nation and Tsay Keh Dene First Nation) and the Tahltan Central Council, "a non-profit society representing the interests of the people of Tahltan ancestry" (para. 4), because their claims to Aboriginal title and other rights in British Columbia gave them an interest in this litigation to determine the western boundary of Treaty 8 . However, as the decision dealt only with their entitlement to intervenor status, I do not interpret it as an acknowledgement that they are the proper holders of title and other rights (although decided just two weeks after Tsilhqot'in Nation, SCC, above note 7, that case was not mentioned).

${ }^{67}$ See McNeil, "Joint Aboriginal Title", above note 32. Note that American law on Aboriginal title is also discussed in this article at 838-52. See especially the analysis at 843-46 of the following cases involving the identity of the title holding group: Confederated Tribes of the Warm Springs Reservation of Oregon $v$. United States, 177 Ct. Cl. 184 (1966); Iowa Tribe of the Iowa Reservation v. United States, 195 Ct. Cl. 365 (1971); Turtle Mountain Band of Chippewa Indians v. United States, 490 F. $2 d 935$ (1974, Ct. Cl.).

${ }^{68}$ See Delgamuukw, above note 5 at para. 155.

${ }^{69} \mathrm{Ibid}$. at para. 159. This does not mean that Aboriginal resource use rights short of title can never be exclusive. If the evidence showed, for example, that one Aboriginal nation fished in a certain lake and excluded all other Aboriginal people from doing so, they could have an exclusive fishing right there, though I would think that exclusion of others should be evidence of sufficient control to establish Aboriginal title. See McNeil, “Joint Aboriginal Title”, above note 32 at 825-34.

${ }^{70}$ In this Part, I look primarily at cases that reached the Supreme Court of Canada that I think are most relevant to the issue of the title holding collective. A more thorough discussion would examine more closely the numerous Aboriginal rights cases that did not reach the highest court, as well as Métis Aboriginal rights cases, starting with Powley, above note 35: see Tsilhqot'in Nation, BCSC, above note 29 at paras. 441-44; Olthuis, above note 2 at 5, 21-25. Compare Tsilhqot'in Nation, BCCA, above note 29 at para. 157. See also note 146 below. 
cases are prosecutions of First Nation individuals, in which it is sufficient for the accused, in order to claim the benefit of an Aboriginal right, to be a member of an Indian Act band or First Nation that has a connection to an Aboriginal people whose practices, customs, or traditions gave rise to the right at the time of contact with Europeans. ${ }^{71}$ Since the issue for the courts in these cases is deciding whether the accused is entitled to the benefit of the claimed Aboriginal right, it is generally not necessary for the judges to specify precisely the collective entity that holds the right today. ${ }^{72}$ Moreover, to the extent that judges have revealed their thinking on this matter, they have usually done so implicitly rather than explicitly. For these reasons, these cases generally shed less light on the identity of the present-day rights holders than the Aboriginal title cases we have already examined.

In addition, the pre-contact social and political organization of the Aboriginal people in question usually does not seem to be a factor in the judges' view of the current rights holding entity. In the leading case of $R . v$. Van der Peet, for example, the Supreme Court apparently accepted that the Sto:lo people as a whole would today have the claimed Aboriginal right to exchange fish for money or other goods (if proven, which the Court decided it had not been), even though the Sto:lo had been "at a band level of social

\footnotetext{
${ }^{71}$ E.g. see R. v. Sparrow, [1990] 1 S.C.R. 1075; Van der Peet, above note 38; R. v. N.T.C. Smokehouse Ltd., [1996] 2 S.C.R. 672; R. v. Adams, [1996] 3 S.C.R. 101 [Adams]; R. v. Côté, [1996] 3 S.C.R. 139. Note that in R. v. Nikal, [1996] 1 S.C.R. 1013 at para. 95, Cory J., writing the majority judgment, observed that "the nature and scope of aboriginal rights will frequently be dependant upon membership in particular bands who have established particular rights in specific localities." However, while membership in a band is generally the way in which individuals establish entitlement to Aboriginal rights, bands are not necessarily the holders of Aboriginal rights. Nonetheless, that could be the situation where a band is the successor to the Aboriginal people whose pre-contact culture gave rise to the right, as seems to be the case of the Heiltsuk Nation whose Aboriginal right to collect and sell herring spawn on kelp in commercial quantities was upheld in R. v. Gladstone, [1996] 2 S.C.R. 723. See also Ahousaht Indian Band v. Canada (Attorney General), 2009 BCSC 1494, [2010] 1 C.N.L.R. 1 [Ahousaht Indian Band, BCSC], discussed in text accompanying notes 98-104 below.

${ }^{72}$ See Ahousaht Indian Band, ibid. at para. 288.
} 
organization rather than at a tribal level” at the time of contact, ${ }^{73}$ and are now organized at the community level into eleven Indian Act bands. ${ }^{74}$

The lack of any real analysis of the issue of the precise identity of the current rights holding entity is particularly evident in cases where the right was not established by the evidence. R. $v$. Pamajewon, ${ }^{75}$ for example, involved appeals from convictions for unlawful gambling of members of two Ojibwa (Anishinabek) Indian Act bands in Ontario, the Shawanaga and Eagle Lake First Nations. They argued that these First Nations have an inherent right of self-government that includes the authority to conduct and regulate gambling activities on their reserve lands. The Supreme Court applied the test for Aboriginal rights laid down by the Court just the day before in Van der Peet, ${ }^{76}$ and upheld the convictions on the ground that the evidence led by the accused failed to prove that high stakes gambling and the regulation thereof had been integral to the distinctive culture of the Ojibwa at the time of contact with Europeans. Chief Justice Lamer observed that the accused relied "in support of their claim on the fact that the 'Ojibwa people ... had a long tradition of public games and sporting events, which pre-dated the arrival of Europeans',"77 but he decided that the limited evidence of this did not establish that it included high stakes gambling. He concluded that the "evidence presented at both the Pamajewon and Gardner trials does not demonstrate that gambling, or that the regulation of gambling, was an integral part of the distinctive cultures of the Shawanaga or Eagle Lake First Nations.” ${ }^{, 78}$ But as those First Nations are actually bands that owe

\footnotetext{
${ }^{73}$ Van der Peet, above note 38 at para. 90.

${ }^{74}$ See the Sto:lo Nation website: http://www.stolonation.bc.ca/bands.

75 [1996] 2 S.C.R. 821 [Pamajewon].

${ }^{76}$ Van der Peet, above note 38.

${ }^{77}$ Pamajewon, above note 75 at para. 26.

${ }^{78}$ Ibid. at para. 28.
} 
their legal existence to the Indian Act, it is questionable whether they could ever meet the Van der Peet test by proving that they had distinctive cultures at the time of contact with Europeans, which by virtue of the fur trade probably occurred for the Ojibwa from whom they are descended long before the Dominion of Canada was even created. Surely Lamer C.J.C. meant that the Ojibwa people from whom they are descended would have had to have a distinctive culture pre-contact that included the practice, custom, or tradition of high stakes gambling. Whether the claimed Aboriginal right, had it been proven in that way, would now be held by the Shawanaga and Eagle Lake First Nations or by some other present-day Ojibwa polity or polities does not appear to have been seriously considered by the Court, ${ }^{79}$ no doubt because it was not necessary to identity the holders of unestablished rights.

Mitchell v. Canada (Minister of National Revenue - M.N.R.) $)^{80}$ involved a claim by an individual member of a First Nation to the benefit of an Aboriginal right, namely to bring goods for trade from the United States into Canada without paying customs duties. Chief Justice McLachlin described Grand Chief Mitchell as "a Mohawk of Akwesasne, a Mohawk community located just west of Montreal, and a descendant of the Mohawk nation, one of the polities comprising the Iroquois Confederacy prior to the arrival of Europeans." ${ }^{81}$ The Supreme Court decided that the alleged right had not been proven, as the evidence of "pre-contact Mohawk trading north of the Canada-United States boundary" was "sparse and tenuous", and trading to the north that did take place was "clearly incidental, and not

\footnotetext{
${ }^{79}$ Lamer C.J.C., ibid. at para. 24, "assum[ed] without deciding that s. 35(1) includes self-government claims," but did not address the issue of how to identify the present-day holders of the right.

${ }^{80}$ [2001] 1 S.C.R. 911.

${ }^{81} \mathrm{Ibid}$. at para. 2.
} 
integral, to the Mohawk culture.”82 In assessing the evidence of trade, the Court's focus was clearly on the Mohawk Nation as a whole, not just on the Akwesasne community that is only one of the Mohawk First Nations in Canada today. ${ }^{83}$

R. v. Sappier; R. v. Gray ${ }^{84}$ involved prosecutions under provincial legislation for unlawfully harvesting wood on Crown lands in New Brunswick. The accused in Sappier are Maliseets and members of the Woodstock First Nation, whereas the accused in Gray is Mi'kmaq and a member of the Pabineau First Nation. In each case, the Supreme Court decided that the accused had established that, as members of their respective First Nations, they had an Aboriginal right to harvest timber for domestic purposes because this practice had been integral to the Maliseet and Mi'kmaq cultures prior to contact with Europeans. Although the Court found that this right to harvest timber is site-specific, Justice Bastarache, in his majority judgment, observed:

At the trial of Messrs. Sappier and Polchies, the Crown conceded that "the issue of territoriality does not arise in the trial of the Defendants on the charge set out herein" (Agreed Statement of Facts at para. 12, reproduced in the trial decision at p. 296). Moreover, in its reply to the defendants' Notice of Contention, the Crown addressed the question of whether the harvesting of trees occurred within Crown lands traditionally used for this practice. The Crown responded: "This question would not appear to be an issue as wood was gathered at will

\footnotetext{
${ }^{82}$ Ibid. at para. 3.

${ }^{83}$ Compare the order of the Federal Court of Appeal (overturned by the Supreme Court), Mitchell v. M.N.R. (C.A.), [1999] 1 F.C. 375 at para. 56, Sexton J.A.: "the plaintiff as a Mohawk of Akwesasne resident in Canada has an existing aboriginal right which is constitutionally protected by sections 35 and 52 of the Constitution Act, 1982, when crossing the international border from New York to Ontario or Quebec, to bring with him to Canada, for personal use or consumption, or for collective use or consumption by the members of the community of Akwesasne, or for non-commercial scale trade with First Nation communities in Ontario or Quebec, goods bought in the State of New York without having to pay any duty or taxes to the government of Canada" [emphasis added].

${ }^{84}$ [2006] 2 S.C.R. 686 [Sappier/Gray].
} 
within the traditional Maliseet territory" (reproduced in the reasons of the Court of Appeal at para. 71). Territoriality is therefore not at issue in the Sappier and Polchies prosecution. ${ }^{85}$

Regarding the Gray case, Bastarache J. noted that

... the trial judge accepted Mr. Sewell's evidence that the Mi'kmaq had traditionally used the Crown lands in question for the purpose of tree harvesting. The Court of Appeal noted that the Crown did not dispute this finding (para. 15). ${ }^{86}$

Yet after deciding that the Aboriginal right had been made out in each case, Bastarache J. concluded:

The respondent Mr. Gray possesses an aboriginal right to harvest wood for domestic uses on Crown lands traditionally used for that purpose by members of the Pabineau First Nation. The respondents Messrs. Sappier and Polchies possess an aboriginal right to harvest wood for domestic uses. That right is also site-specific, such that its exercise is necessarily limited to Crown lands traditionally harvested by members of the Woodstock First Nation. ${ }^{87}$

With all due respect, I find this conclusion difficult to reconcile with the Crown's admission in Sappier that "wood was gathered at will within the traditional Maliseet territory” and the Court's consequent conclusion that "[t]erritoriality is therefore not at issue in the Sappier and Polchies prosecution.” ${ }^{88}$ Nor is it consistent with the undisputed "evidence that the Mi'kmaq had traditionally used the Crown lands in question for the purpose of tree harvesting." ${ }^{89}$ There does not appear to have been any evidence (at least not evidence referred to by the Supreme Court) that a Mi'kmaq

\footnotetext{
${ }^{85} \mathrm{Ibid}$. at para. 52. Note that the meaning of the term "territoriality" in this context is unclear, as it is not defined in the Agreed Statement of Facts, reproduced at trial in R. v. Sappier, [2003] 2 C.N.L.R. 294 (N.B. Prov. Ct.), para. 2, or in the judgments.

${ }^{86}$ Ibid. at para. 53.

${ }^{87}$ Ibid. at para. 72 [emphasis added].

${ }^{88}$ See quotation at note 85 above.

${ }^{89}$ See quotation at note 86 above.
} 
subgroup connected to the present-day Pabineau First Nation or a Maliseet subgroup connected to the current Woodstock First Nation even existed at the time of contact, let alone restricted their wood harvesting to defined portions of the Mi'kmaq and Maliseet territories. ${ }^{90}$ Surely it would have been more consistent with the evidence referred to by the Supreme Court to conclude that Mr. Gray has an Aboriginal right to harvest wood wherever the Mi'kmaq harvested pre-contact, and Messrs. Sappier and Polchies likewise where the Maliseet harvested. ${ }^{91}$

Unlike the other Aboriginal rights cases we have considered, Lax Kw'alaams Indian Band v. Canada (Attorney General) ${ }^{92}$ did not involve a prosecution. It was a representative action brought by "Chief Councillor Garry Reece on his own behalf and on behalf of the members of the Lax Kw'alaams Indian Band and others” ${ }^{93}$ for a declaration of their right to fish commercially in designated waters along the coast of British Columbia. Delivering the unanimous decision of the Supreme Court, Justice Binnie described the action as "the claim of the Lax Kw'alaams First Nation and other First Nations listed in the Appendix to these reasons (herein collectively referred to as 'Lax Kw'alaams'), whose ancestral lands stretch

\footnotetext{
${ }^{90}$ At trial in R. v. Sappier, [2003] 2 C.N.L.R. 294 at para. 12, Cain Prov. Ct. J. referred in general terms to "the distinctive culture of the ancestors of the Woodstock First Nation in pre-European times." The trial decision in $R$. v. Gray does not appear to have been reported, but the trial judge's finding in relation to this issue were summarized by Robertson J.A. in the New Brunswick Court of Appeal, R. v. Gray, [2004] 4 C.N.L.R. 201 at para. 5: "Second, he held that the trees in question were harvested from lands traditionally occupied by Mr. Gray's ancestors. Third, the trial judge concluded that the expert evidence of Mr. Sewell established that the Mi'kmaq traditionally used wood and that they continue to do so." In his Supreme Court judgment, Sappier/Gray, above note 84 at para. 27, Bastarache J. described the main issue as "whether the practice of harvesting wood for domestic uses was integral to the distinctive culture of the Maliseet and Mi'kmaq, pre-contact" [emphasis added].

${ }^{91}$ The Court's apparent concern to limit the geographical scope of the right would no doubt be met by the practical reality that members of these First Nations would be unlikely to travel far from their communities to harvest wood if the resource was available closer to home. The Court's confinement of the right to domestic uses would reinforce this practical limitation.

${ }_{92}$ Lax Kw'alaams, above note 38.

${ }^{93}$ Ibid., style of cause.
} 
along the northwest coast of British Columbia between the estuaries of the Nass and lower Skeena rivers, to the commercial harvesting and sale of 'all species of fish' within their traditional waters."94 Those First Nations are apparently descended from the Coast Tsimshian people who inhabited that region when the Europeans first arrived around $1793 .{ }^{95}$ The evidence led to prove the Aboriginal right therefore related to the fishing practices, customs and traditions of the Coast Tsimshian people as a whole prior to this European contact. Regarding the identity of the current rights holders, the statement of claim asked for "a declaration that the Lax Kw'alaams or, in the alternative, each of the Allied Tsimshian Tribes, have existing aboriginal rights”, but the trial judge restated this as an application for declarations that "the plaintiffs have an existing Aboriginal right". ${ }^{96}$ Given the representative nature of the action, the term "plaintiffs" may be vaguer than "Lax Kw'alaams or, in the alternative, each of the Allied Tsimshian Tribes”, but the precise identity of the current rights holders was never clarified because the courts, all the way up to the Supreme Court, decided that the right to a commercial fishery had not been proven. Binnie J. agreed with the trial judge that the Coast Tsimshian's pre-contact trade in eulachon grease did not provide a sufficient basis for "a modern right to fish commercially all species” in that people's traditional territory. ${ }^{97}$

Although not a case decided by the Supreme Court of Canada, Ahousaht Indian Band v. Canada (Attorney General) ${ }^{98}$ deserves our

\footnotetext{
${ }^{94}$ Ibid. at para. 1. The First Nations listed in the Appendix are the Ginaxangiik Tribe, Gitandoah Tribe, Gitwilgiots Tribe, Git'tsiis Tribe, Gitnadoiks Tribe, Gispaxloats Tribe, Gitlan Tribe, Gitzaxlaal Tribe, and Gitlutzau Tribe.

${ }^{95}$ See ibid. at para. 15: "The Lax Kw'alaams First Nation consists of the descendants of an ancient 'fishing people' comprising the several tribes or houses of the Coast Tsimshian."

${ }_{96}^{96}$ Ibid. at paras. 25-26.

${ }^{97}$ Ibid. at para. 30.

${ }^{98}$ Ahousaht Indian Band, BCSC, above note 71.
} 
attention because, like Lax Kw'alaams, it involved claims to commercial fisheries (as well as Aboriginal title, which the court found it unnecessary to address $^{99}$ ), and because the identity of the rights holders was a significant issue at trial. The plaintiffs are five Indian Act bands, the Ehattesaht, Mowachaht/Muchalaht, Hesquiaht, Ahousaht and Tla-o-qui-aht, on Vancouver Island. They claimed that,

... before and at the time of contact with Europeans, their predecessors (collectively, the "Nuu-chah-nulth Nations") existed as organized and self-governing social and political entities. They claim that the Nuu-chah-nulth Nations are culturally related groups that share common distinctive features including language, customs, practices, traditions, laws, economies, spiritual beliefs and culture. After British Columbia's entry into Confederation in 1871, each of the Nuuchah-nulth Nations was constituted as a band under the predecessor of the Indian Act, R.S.C. 1985, c.I-5, and, today, each band is the legal representative of its predecessor Nation and the lawful holder of the collective Aboriginal rights and title of that Nation. ${ }^{100}$

Justice Garson stated that, in order to succeed in their Aboriginal rights claims, the plaintiffs had to "establish that they are the successor collectives to the Aboriginal groups that possessed Aboriginal rights at the date of contact.... The question to be resolved is whether these modern plaintiffs can prove that they are rights holders; that is, are they connected to the groups from whom they say they derive their Aboriginal rights to fish and to trade in fish." ${ }^{101}$ Garson J. examined the relevant evidence at length in her judgment, and concluded that each of the five bands had proven a sufficient connection with the pre-contact Nuu-chah-nulth Nation, from

\footnotetext{
${ }^{99}$ Ibid. at paras. 491-502.

${ }^{100}$ Ibid. at para. 7.

${ }^{101} \mathrm{Ibid}$. at para. 287. See also the quotation from Marshall/Bernard, above note 6, accompanying note 38 above.
} 
which they claimed to be descended, to be the present-day rights holders in that Nation's traditional territory. ${ }^{102}$ She accordingly ordered, among other things, that "[t]he plaintiffs have Aboriginal rights to fish for any species of fish in the environs of their territories and to sell fish. The approximate boundaries of each plaintiff's territory is [sic] delineated in Appendix A and further particularized for each plaintiff at Exhibit 26, with the exception of the seaward boundary. The seaward boundary is nine miles from a line drawn from headland to headland within each plaintiff's territory." 103 Justice Garson's decision was upheld by the B.C. Court of Appeal, with one variation: geoduck clams were excluded from the plaintiffs' Aboriginal fishing rights because the Nuu-chah-nulth could not have engaged in this modern, high-tech fishery at the time of contact. ${ }^{104}$

One other Supreme Court of Canada decision deserves to be mentioned, even though it involved a claim to treaty rights rather than Aboriginal rights, because the Court made some general statements about rights holders that are applicable to both categories of rights. Behn $v$. Moulton Contracting Ltd. ${ }^{105}$ was a tort action brought by a forestry company against members of the Behn family, who belong to the Fort Nelson First Nation (FNFN) in British Columbia, for blockading a logging road providing access to an area where the company had been granted timber harvesting licences by the province. The defendants argued that the licences were invalid because the province had not consulted with them prior to

\footnotetext{
${ }^{102}$ Ibid. at paras. 287-365.

${ }^{103}$ Ibid. at para. 909.

1042011 BCCA 237, [2011] 3 C.N.L.R. 1, affirmed on rehearing, 2013 BCCA 300, [2013] 4 C.N.L.R 31. The rehearing took place because, on appeal of the B.C.C.A.'s original judgment, the Supreme Court of Canada ordered the case to be remanded to that court to be reconsidered in light of the Supreme Court's decision in Lax Kw'alaams, above note 38: [2011] S.C.C.A. No. 353. Note that a follow-up decision is awaited on the issue of justifiable infringement of the Aboriginal right to fish commercially: see http://www.jfklaw.ca/justifying-canadas-infringement/.

${ }^{105}$ Behn, above note 31 .
} 
issuing the licences and because the licences infringed their treaty hunting and trapping rights. The company responded by arguing that the Behns lacked standing to raise the issues of consultation and treaty rights as defences because the rights are held by the FNFN, not by individual members or families. ${ }^{106}$ The Behns' answer to this was summarized by Justice LeBel, who delivered the Court's unanimous judgment, as follows:

They recognize that these rights have traditionally been held by the FNFN, which is a party to Treaty No. 8. But they also allege that specific tracts of land have traditionally been assigned to and associated with particular family groups. They assert in their pleadings that the Authorizations granted to Moulton are for logging in specific areas within the territory traditionally assigned to the Behns, where they have exercised their rights to hunt and trap. ${ }^{107}$

The Supreme Court decided that raising the consultation and treaty rights defences in this action was an abuse of process because the FNFN and the Behns had notice of the licences and should have challenged their validity in an action for judicial review before the company started work. The Court therefore declined to rule on the treaty rights issue, but Justice

\footnotetext{
${ }^{106}$ For other cases involving the issue of standing in relation to treaty rights, see Komoyue Heritage Society v. British Columbia (Attorney General), 2006 BCSC 1517 [Komoyue Heritage Society]; Kelly v. Canada (Attorney General), 2013 ONSC 1220, [2013] 3 C.N.L.R. 333. In Kelly, an action alleging that the government of Canada has not fulfilled its obligations in Treaty 3 in relation to education, Perell J. stated: "Aboriginal rights are communal rights, but the rights holder, i.e., the aboriginal group that shares the right may be a family, a clan, a descent group, a hunting party, an encampment, a band, a tribe, a confederacy or a first nation.... Aboriginal rights and treaty rights are collective rights, and the proper party with the standing to assert an aboriginal rights claim or a treaty rights claim is the collective that is the rights holder.” In this representative action, Perell J. opined at para. 121 that, if the matter were justiciable (which he decided it was not), the plaintiff chief would be "able to bring a representative action on behalf of the beneficiaries of Treaty 3 provided that: (1) he was authorized to do so by all of the 28 reserve bands (by band council resolutions); or (2) if he joins as party defendants those bands that do not authorize his representation action.” The Ontario Court of Appeal reversed Perell J.s decision that the action was not justiciable, and agreed that the representative action could go ahead if the conditions he imposed were met: 2014 ONCA 92 at para. 21. See also Kelly v. Ontario (Minister of Energy), 2014 ONSC 5492, [2015] 1 C.N.L.R. 206, Perell J.at para.19: "Aboriginal and treaty rights are communal rights and belong to communities that may be comprised of families, clans, descent groups, hunting parties, a band, a tribe, a confederacy or a First Nation. Who is the holder of an Aboriginal or Treaty right is contestable, and the determination of who is the rights holder may require a fact-based determination.”

${ }^{107}$ Behn, above note 31 at para. 36.
} 
LeBel did make some general comments about the holders of Aboriginal and treaty rights that are relevant to our discussion:

Aboriginal and treaty rights are collective in nature: see $R$. $v$. Sparrow, [1990] 1 S.C.R. 1075, at p. 1112; Delgamuukw, [above note 5] at para. 115; R. v. Sundown, [1999] 1 S.C.R. 393, at para. 36; R. v. Marshall, [1999] 3 S.C.R. 533, at paras. 17 and 37; R. v. Sappier, 2006 SCC 54, [2006] 2 S.C.R. 686, at para. 31; Beckman, [Beckman v. Little Salmon/Carmacks First Nation, [2010] 3 S.C.R. 103] at para. 35. However, certain rights, despite being held by the Aboriginal community, are nonetheless exercised by individual members or assigned to them. These rights may therefore have both collective and individual aspects. Individual members of a community may have a vested interest in the protection of these rights. ${ }^{108}$

After declining to try to categorize Aboriginal and treaty rights any more precisely along collective and individual lines, LeBel J. concluded:

... on the occasion of this appeal and at this stage of the development of the law, ... [i]t will suffice to acknowledge that, despite the critical importance of the collective aspect of Aboriginal and treaty rights, rights may sometimes be assigned to or exercised by individual members of Aboriginal communities, and entitlements may sometimes be created in their favour. In a broad sense, it could be said that these rights might belong to them or that they have an individual aspect regardless of their collective nature. Nothing more need be said at this time. ${ }^{109}$

It is clear from the cases we have already examined that individuals can successfully rely on Aboriginal rights as a defence to prosecutions. One would therefore think that they should be able to rely on those rights in civil cases as well. Be that as it may, our concern in this discussion paper is the identity of the current holders of collective rights. In Behn, it seems to have

\footnotetext{
${ }^{108}$ Ibid. at para. 30.

${ }^{109} \mathrm{Ibid}$. at para. 31.
} 
been assumed that the FNFN, an Indian Act band, is the holder of those rights in the area where the logging was taking place. ${ }^{110}$ However, treaty rights are different from Aboriginal rights in this regard because the treaty records and documents provide direct evidence of the Aboriginal parties, whereas the identity of the Aboriginal peoples whose practices, customs, and traditions form the basis for Aboriginal rights depends more generally on historical, ethnographic, and other sources of evidence. As a result, and because the treaties are usually closer in time to the present, it is often easier to make a connection between parties who entered into the treaties and the present-day holders of collective treaty rights than it is to make a connection between Aboriginal peoples at the time of contact and the holders of Aboriginal rights today. ${ }^{111}$

This brief survey of some of the Supreme Court decisions involving claims by First Nations to Aboriginal rights apart from title reveals that the Court's approach has generally been to determine whether the individuals claiming the benefit of the right are members of a First Nation or Indian band today that has a connection with an Aboriginal people for whom the practice, custom, or tradition on which the alleged right is based was integral

\footnotetext{
${ }^{110}$ See note 117 below. See also Fort Nelson First Nation v. British Columbia (Environmental Assessment Office), 2015 BCSC 1180, [2015] 4 C.N.L.R. 104, where Davies J. held that the province owes a duty to consult to the FNFN in relation to the development of a sand and gravel pit within their traditional territory. ${ }^{111}$ The Supreme Court has refused to impose too high a standard for establishing such a connection in the case of treaty rights. In R. v. Simon, [1985] 2 S.C.R 387 at 407, Dickson C.J.C., delivering the unanimous judgment, responded to the Crown's argument that the appellant had "not shown that he is a direct descendant of a member of the original Micmac Indian Band covered by the Treaty of 1752" (the treaty the appellant relied upon as a defence to the charge of unlawful hunting): "In my view, the appellant has established a sufficient connection with the Indian band, signatories to the Treaty of 1752 . As noted earlier, this Treaty was signed by Major Jean Baptiste Cope, Chief of the Shubenacadie Micmac tribe, and three other members and delegates of the tribe. The Micmac signatories were described as inhabiting the eastern coast of Nova Scotia. The appellant admitted at trial that he was a registered Indian under the Indian Act, and was an 'adult member of the Shubenacadie-Indian Brook Band of Micmac Indians and was a member of the Shubenacadie Band Number 02'. The appellant is, therefore, a Shubenacadie-Micmac Indian, living in the same area as the original Micmac Indian tribe, party to the Treaty of 1752 . This evidence alone, in my view, is sufficient to prove the appellant's connection to the tribe originally covered by the Treaty."
} 
to their distinctive culture at the time of contact with Europeans. The Court does not appear to be too concerned with precise definition of the rights holding entity, either at the time of contact or in the present day. As long as there is a sufficient connection between the relevant Aboriginal people at contact and the current Aboriginal community to which the individuals belong, that seems to meet the continuity requirement for the claimants of the Aboriginal right today. However, where the individuals are members of a subgroup within a larger entity such as an Aboriginal nation, it does not mean that the subgroup is the holder of the right. ${ }^{112}$ For example, if Dorothy Van der Peet had been able to establish an Aboriginal right to exchange fish for money or other goods in Van der Peet, it seems that all members of the Sto:lo Nation, not just members of the Sto:lo band or First Nation to which she belongs, would have the benefit of that right today. Similarly, if Chief Mitchell had been able to prove the trading right in the Mitchell case, presumably all Mohawk communities in Canada, not just the Mohawks of Akwesasne, would be the holders of the right. ${ }^{113}$

\footnotetext{
112 Though Sappier/Gray, above note 84, may appear inconsistent with this conclusion, as discussed above in the text accompanying notes 85-91 I think there are problems with this aspect of the decision. The Court's concern seems to have been to limit the territorial scope of the wood harvesting right, but in so doing I think the judges did not take sufficient account of the admissions and evidence regarding the identity of the Aboriginal peoples - the Maliseet and Mi'kmaq peoples - whose pre-contact activities gave rise to the harvesting right. With respect, I think Bastarache J.'s leap in logic in this regard is evident in the following passage at para. 53 of his judgment: "In the Gray trial, the trial judge accepted Mr. Sewell's evidence that the Mi'kmaq had traditionally used the Crown lands in question for the purpose of tree harvesting. The Court of Appeal noted that the Crown did not dispute this finding (para. 15). I would conclude on this basis that Mr. Gray has established an Aboriginal right to harvest wood for domestic uses on Crown lands traditionally used for this purpose by members of the Pabineau First Nation" [emphasis added]. How, one might ask, does the factual finding that "the Mi'kmaq had traditionally used the Crown lands in question for the purpose of tree harvesting" get transformed into a conclusion relating to "Crown lands traditionally used for this purpose by members of the Pabineau First Nation”?

${ }^{113}$ Similarly, in Adams, above note 71, the accused, also an Akwesasne Mohawk, was found to have an Aboriginal right to fish for food in Lake St. Francis in Quebec because fishing there was integral to the distinctive culture of the Mohawks prior to contact with Europeans. Nothing in Lamer C.J.C.'s decision suggests that only the Mohawks of Akwesasne have this right. At para. 34, he stated: "The appellant argues that the Mohawks have an aboriginal right to fish in Lake St. Francis. In order to succeed in this argument the appellant must demonstrate that, pursuant to the test laid out by this Court in Van der Peet, fishing in
} 
So far we have examined cases where a claim to Aboriginal title or some other Aboriginal right was asserted and an attempt was made to prove that title or right in court. In other cases, title and other rights are claimed, not in order to get a court declaration of their existence or as a defence against prosecution, but rather to force governments to consult with the Indigenous people concerned before resource development or other activity, such as the building of dams or infrastructure, goes ahead in their territory. These cases raise the issue of determining whom governments need to consult with in specific instances, which of course depends on the identity of the collectives claiming Aboriginal title or rights at the time when consultation must take place. We will now examine some of these cases.

\section{Duty to Consult Cases ${ }^{114}$}

In the leading case of Haida Nation v. British Columbia, ${ }^{115}$ the Supreme Court decided that the Crown (in this case the Crown in right of the province) has a constitutional duty to consult with Aboriginal peoples when it contemplates action that might have some adverse impact on their Aboriginal rights, even if those rights have only been claimed but not yet established in court or acknowledged by a historical treaty or modern land claims agreement. The Court found that British Columbia had not consulted with the Haida people when it modified a tree farm licence that permitted harvesting of timber on Haida Gwaii (formerly the Queen Charlotte Islands) and when it later transferred the licence to another forestry company. This

Lake St. Francis was 'an element of a practice, custom or tradition integral to the distinctive culture' of the Mohawks. For the reasons given below, I am of the view that the appellant has satisfied this test.”

${ }^{114}$ The discussion in this Part is limited to selective Aboriginal title and rights cases, and so does not consider cases involving treaty rights.

115 [2004] 3 S.C.R. 511 [Haida Nation, SCC]. 
decision, along with Taku River Tlingit First Nation v. British Columbia, ${ }^{116}$ a companion case decided the same day, set the stage for a stream of duty to consult cases in British Columbia and elsewhere in Canada. No attempt will be made in this discussion paper to provide anything like a comprehensive survey of these numerous cases. Instead, we will focus on a few selected decisions that cast some light on the identity of the rights holders or claimants with whom consultation must take place. For as Justice LeBel stated in the Behn decision,

[t]he duty to consult exists to protect the collective rights of Aboriginal peoples. For this reason, it is owed to the Aboriginal group that holds the s.35 rights, which are collective in nature.... But an Aboriginal group can authorize an individual or an organization to represent it for the purpose of asserting its s.35 rights. ${ }^{117}$

\footnotetext{
116 [2004] 3 S.C.R. 550 [Taku River].

${ }^{117}$ Behn, above note 31 at para. 30. As authority, LeBel J. cited Komoyue Heritage Society, above note 106. See also Behn at para. 31: "given the absence of an allegation of an authorization from the FNFN [Fort Nelson First Nation], in the circumstances of this case, the Behns cannot assert a breach of the duty to consult on their own, as that duty is owed to the Aboriginal community, the FNFN." See also Beckman v. Little Salmon/Carmacks First Nation, [2010] 3 S.C.R. 103 at para. 35. In John Voortman \& Associates Limited v. The Haudenosaunee Confederacy Chiefs Council, [2009] 3 C.N.L.R. 117 at para. 73 (Ont. S.C.), Henderson J. decided that no duty to consult was owed to Haudenosaunee Men's Fire of Grand River (HMF) in relation to a land claim because "the HMF is not well defined and its authority to represent Aboriginal people is not well established." Similarly, in Fond du Lac Denesuline First Nation v. Canada (Attorney General), 2010 FC 948, [2010] 4 C.N.L.R. 1 at para. 163 (affirmed, without addressing this issue, 2012 FCA 7, 430 N.R. 190), Russell J. decided that "Camsell Portage, Uranium City, Stony Rapids and Wollaston Lake [municipalities in northern Saskatchewan] may well have Aboriginal residents and connections to Aboriginal communities, but these entities themselves do not enjoy section 35 rights. Counsel for the Applicants has explained that these entities are being used in a convenient representative capacity for the Aboriginal members of their respective communities, but there is nothing before the Court to show how they acquired this representative capacity and whether they are truly authorized to make this application on behalf of the Aboriginal members of their communities. Consequently, in so far as this application depends upon section 35 rights and the duty of the Crown to consult with Aboriginal groups or persons, Camsell Portage, Uranium City, Stony Rapids and Wollaston Lake have not established that they have standing." See also Native Council of Nova Scotia v. Canada (Attorney General), 2007 FC 45, [2007] 2 C.N.L.R. 233 at paras. 42-44 (affirmed 2008 FCA 113, [2008] 3 C.N.L.R. 286, without addressing this issue), where Layden-Stevenson J. was willing to assume that the Native Council of Nova Scotia (NCNS) could represent Mi'kmaq and other Aboriginal persons living off-reserve in Nova Scotia in consultations in relation to their alleged Aboriginal right to fish. He stated at para. 43: "Because the off-reserve Aboriginal population of Nova Scotia chose the NCNS to represent them in their dealings with DFO [Department of Fisheries and Oceans], the NCNS (as an organization) holds the procedural right of consultation while its individual members hold the substantive right to fish.” However, because there was a paucity of evidence
} 
In the Haida Nation case itself, the style of cause described the plaintiffs as the "Council of the Haida Nation and Guujaaw, on their own behalf and on behalf of all members of the Haida Nation". ${ }^{118}$ The portion of the declaration of the B.C. Court of Appeal that was affirmed by the Supreme Court declared that the Crown in right of the province has "a legally enforceable duty to the Haida people to consult with them in good faith and to endeavour to seek workable accommodations between the Aboriginal interests of the Haida people, on the one hand, and the short term and long term objectives of the Crown”. ${ }^{119}$ In the Supreme Court judgment, the duty is said to be owed to the "Haida people", or just the "Haida", as they are the people with a strong claim to Aboriginal title and other Aboriginal rights. Writing the unanimous judgment, Chief Justice McLachlin observed: "The Haida have claimed title to all of Haida Gwaii for at least 100 years." 120

The website of the Haida Nation states:

The Haida Nation collectively holds Hereditary and Aboriginal Title and Rights to Haida Territories and the cultural and intellectual property rights of the Haida Nation. All people of Haida ancestry are citizens of the Haida Nation. Every Haida citizen has the right of access to all Haida Gwaii resources for cultural reasons, and for food or commerce consistent with the Laws of Nature as reflected in the laws of the Haida Nation. ${ }^{121}$

of the alleged right for members of the NCNS other than Mi'kmaq members, the NCNS could not claim it was owed a duty to consult on behalf of all its members.

${ }^{118}$ Haida Nation, SCC, above note 115, style of cause. Guujaaw was the President of the Council of the Haida Nation at the time: see CBC News, “Innovative Haida leader Guujaaw steps aside”, 11 December 2012, online: http://www.cbc.ca/news/canada/british-columbia/innovative-haida-leader-guujaaw-stepsaside-1.1200975.

${ }^{119}$ Haida Nation v. British Columbia, [2002] 2 C.N.L.R. 121 at para. 60.

${ }^{120}$ Haida Nation, SCC, above note 115 at para. 65,

${ }^{121}$ Online: http://www.haidanation.ca/Pages/history/haidanation.html. Legal expression of this is in the Constitution of the Haida Nation, Art. 3, online:

http://www.haidanation.ca/Pages/governance/pdfs/HN\%20Constitution\%20Revised\%20Oct\%202014_offic ial\%20unsigned\%20copy.pdf. 
In affirming that the duty to consult is owed to the Haida people, the Supreme Court's judgment is consistent with the Haida's own assertion that the whole Haida Nation has a collective right to their lands and resources that can be accessed by every Haida citizen. Distribution of governmental authority within the Haida Nation therefore does not affect and is not relevant to the identity of the title and rights holder, which is the Haida people collectively rather than a governing body. ${ }^{122}$ However, according to Justice LeBel in the Behn decision, the Haida people can delegate authority to a governing body or individuals to represent them in consultations in relation to their Aboriginal title and other rights. In my opinion, such a delegation would be an exercise of the Haida Nation's governance authority over their title and other rights. ${ }^{123}$

In the Taku River case, the Supreme Court held unanimously that the Taku River Tlingit First Nation (TRTFN), an Indian Act band, "have prima facie Aboriginal rights and title over at least some of the area that they claim”, ${ }^{24}$ and consequently the province owed them a duty to consult in relation to construction of a road through their traditional territory. The Court noted that the province clearly had notice of the claims of the TRTFN, as they had been attempting to negotiate their land claim with Canada since 1983 and with British Columbia after the B.C. Treaty Commission was established in $1993 .{ }^{125}$ While it is not clear from the judgment that the TRTFN had received authority from the members of the TRTFN to negotiate the land claim and challenge the construction of the road, this was likely

\footnotetext{
${ }^{122}$ The Constitution of the Haida Nation, ibid., provides for governmental authority to be distributed among the Council of the Haida Nation, the Hereditary Chiefs' Council, and two village councils, Old Massett Village Council and Skidegate Band Council. The village councils are Indian Act band councils: see First Nation Profiles Interactive Map, online: http://fnpim-cippn.aandc-aadnc.gc.ca/index-eng.html.

${ }^{123}$ See note 32 and accompanying text above.

${ }^{124}$ Taku River, above note 116 at para. 30.

${ }^{125} \mathrm{Ibid}$. at para. 26.
} 
assumed, especially as the style of cause indicates that the action was brought by the "Taku River Tlingit First Nation and Melvin Jack, on behalf of himself and all other members of the Taku River Tlingit First Nation”. ${ }^{26}$

Comparing Haida Nation and Taku River, we see that in the former case the duty to consult was owed to the Haida people as a whole, not to their governing bodies which include two Indian Act band councils, whereas in Taku River the duty was owed to the TRTFN, an Indian Act band. In neither case does the identity of the claimants to Aboriginal rights and title seem to have been an issue. Instead, the Supreme Court appears to have simply assumed that the claimants had the authority that they asserted by bringing the proceeding. ${ }^{127}$ It would therefore seem that, unless someone challenges the authority of the Aboriginal people or polity claiming to be owed a duty to consult, judges usually will not raise the issue themselves by questioning that authority. ${ }^{128}$

\footnotetext{
${ }^{126}$ Ibid., style of cause.

${ }^{127}$ See also Rio Tinto Alcan Inc. v. Carrier Sekani Tribal Council, [2010] 2 S.C.R. 650, where the Carrier Sekani Tribal Council (CSTC) alleged that its member tribes have Aboriginal rights and title in the Nechako River watershed in British Columbia, giving rise to a duty to consult in relation to sale of electricity from a hydroelectric facility built on the river in the 1950s. While the Supreme Court held that there was no duty to consult in relation to the sale of electricity because it would not have a new adverse impact on the claimed rights, it did not question the authority of the CSTC to bring the action.

${ }^{128}$ E.g. see Ktunaxa Nation v. British Columbia (Minister of Forests, Lands and Natural Resource Operations), 2014 BCSC 568, [2014] 4 C.N.L.R. 143, aff'd 2015 BCCA 352, [2015] 4 C.N.L.R. 199, leave to appeal granted by the S.C.C., 17 March 2016. Compare the cases cited in note 117 above. See also Hamlet of Clyde River, above note 2, where a challenge to standing of the Nammautaq Hunters \& Trappers Organization -- Clyde River to represent the collective rights holding body under the Nunavut Land Claims Agreement in a duty to consult case was dealt with by the court granting that organization public interest standing. Leave to appeal this decision was granted by the Supreme Court on March 10, 2016. Though not a case where such a challenge was made, Halalt First Nation v. British Columbia (Minister of Environment), 2012 BCCA 191, involving applications for intervenor status in a duty to consult case, reveals another situation in which this issue could arise. The Cowichan Tribes, who are members of the Hul'qumi'num Treaty Group (HTG), to which the Halalt First Nation (the plaintiff in the case) also belongs, argued that "the strength-of-claim assessment required by the duty to consult must include consideration of which present-day Aboriginal community is likely the proper rights holder. It says if that issue had been considered in this case, the Province would not have erred in concluding that the Halalt's aboriginal title claim to the well sites was weak. It submits that the Province should have recognised that the HTG member communities as a group are the likely proper rights holders of a strong claim to Aboriginal title" (para. 25). Smith J.A. denied intervenor status to the Cowichan Tribes without discussion
} 
While not attempting a comprehensive survey, it is worth examining a couple of lower court decisions where the issue of the identity of the Aboriginal title or rights claimants did arise. ${ }^{129}$ Nlaka'pamux Nation Tribal Council v. Griffin ${ }^{130}$ involved the duty to consult in relation to a proposal to extend a landfill site that could have an adverse impact on Aboriginal rights and title. As the landfill site was on or close to the boundary between the traditional territories of two Aboriginal nations, the Secwepemc Nation (formerly called the Shuswap Nation) and the Nlaka'pamux Nation (formerly called the Thompson River Nation), and the plaintiff Nlaka'pamux Nation Tribal Council (NNTC) represented some but not all of the Indian Act bands belonging to the Nlaka'pamux Nation, a question arose as to whether a duty to consult was owed to the NNTC. On this application for judicial review, Justice Sewell said this:

What is the government to do when faced with a diversity of putative representation on behalf of a First Nation. In my view, the government must discharge its duty to consult by taking reasonable steps to ensure that all points of view within a First Nation are given appropriate consideration. ${ }^{131}$

While making a preliminary assessment that the Nlaka'pamux Nation's Aboriginal title claim at the location of the proposed landfill extension was weak, Sewell J. nonetheless decided that a duty to consult was owed to the NNTC, even though one of the bands within the NNTC opposed its position

of the issue of the proper rights holder, as “[t]his issue is being proposed for the first time on appeal and, in any event, could be advanced by Halalt if it so wishes” (para. 30).

${ }^{129}$ For other case references and very useful discussion, see Kerry Wilkins, “Aboriginal Law: The Duty to Consult: To Whom Is the Duty Owed”, Ontario CED, $4^{\text {th }}$ ed. (Toronto: Carswell, 2008-), vol. 1, title 2 at $\S 10$; Janna Promislow, “Consultation Update: Emerging and Persistent Issues”, paper delivered at the Constitutional Law Symposium, co-sponsored by the Legal Education Society of Alberta and the Centre for Constitutional Studies, University of Alberta, 28 September 2012 [unpublished], at 25-31; Dwight G.

Newman, Revisiting the Duty to Consult Aboriginal Peoples (Saskatoon: Purich Publishing, 2014), 65-71.

1302009 BCSC 1275, [2009] 4 C.N.L.R. 213 [Nlaka'pamux Nation].

${ }^{131}$ Ibid. at para. 73 . 
on the extension of the landfill site and challenged its authority to represent the Nlaka'pamux people in this matter. ${ }^{132}$ Justice Sewell avoided the internal disagreement by deciding that a duty to consult was also owed to the dissenting band.

In Campbell v. British Columbia (Minister of Forests and Range), ${ }^{133}$ the petitioners sought an interim injunction to stop logging pending judicial review of a licence issued by the province to Sunshine Logging Ltd., permitting it to harvest timber from four cut blocks on Perry Ridge between the Slocan and Little Slocan rivers in southern British Columbia, in an area entirely within the territory over which the Sinixt people claim Aboriginal title. The petitioners, who are directors of the Sinixt Nation Society, a representative body of the Sinixt Nation, brought the action on their own behalf and on behalf of the Sinixt Nation and the Sinixt Nation Society. ${ }^{134}$ The judgment relates to an application by the defendant Minister for an order dismissing the petition on the ground that "the petitioners are without authority to advance the claims or obtain the relief sought, and that they lack the requisite standing to bring the petition.”135 Justice Willcock noted that "[t]his is as much a challenge to the claim of the collective on behalf of whom the petitioners purport to act as a challenge to the capacity or fitness of the individual petitioners to act for that collective." ${ }^{136}$ He observed that

\footnotetext{
${ }^{132}$ This aspect of his decision was upheld on appeal: Nlaka'pamux Nation Tribal Council v. British Columbia (Project Assessment Director, Environmental Assessment Office), 2011 BCCA 78, [2011] 2 C.N.L.R. 186 [NNTC]. On the practical difficulties facing the Crown in this kind of situation, Groberman J.A., delivering the judgment, observed at para. 68: "Like the chambers judge, I have some sympathy for the Project Assessment Director in this case. Faced with competing claims and obvious animosity among the First Nations groups that were demanding consultation, the task of creating an efficient and meaningful consultative process was a daunting one.” See also discussion of his decision in Tsilhqot'in Nation, BCCA, in text accompanying notes 48-52 above.

1332011 BCSC 448, [2011] 3 C.N.L.R. 151 [Campbell].

${ }^{134}$ Ibid., style of cause.

${ }^{135}$ Ibid. at para. 7.

${ }^{136}$ Ibid.
} 
"[i]t is common ground that the rights asserted by the petitioners are collective rights and that legal action brought to determine or enforce those rights must be brought on behalf of a group that is capable of advancing a claim under s.35 of the Constitution Act, 1982.”137

The Aboriginal title claim of the Sinixt people, upon which the alleged breach of the duty to consult depended in this case, is uncommon among claims by First Nations in Canada, in that these people do not currently have federally acknowledged status as an Indian Act band or bands. There was, however, no real question of their existence as an Aboriginal people prior to the arrival of Europeans. Justice Willcock observed:

The evidence before me is that a relatively distinct aboriginal population made use of and occupied land between the Monashee and Selkirk Mountains, from the Kettle River north to the area of present-day Revelstoke, for a period of approximately 3,500 years, up to the time of contact with European explorers and settlers. The record also establishes that following contact, the Sinixt's numbers in Canada were reduced by disease and their gradual displacement south into the United States. ${ }^{138}$

Tragically, the Sinixt never recovered from the decimation caused by a smallpox epidemic in the late $1700 \mathrm{~s}$. By the early $20^{\text {th }}$ century, most of their members had gone to live in the United States, particularly on the Colville Indian Reservation that had been created in 1872 in what became Washington State. Although a reserve at Oakscott in British Columbia was created for the Arrow Lakes Band of Sinixt by the Canadian government in 1915, by 1924 apparently only eight members of this band remained. After

\footnotetext{
${ }^{137}$ Ibid. at para. 9.

${ }^{138}$ Ibid. at para.15.
} 
the last registered member, Annie Joseph, died on October 1, 1953, the federal government declared the Arrow Lakes Band to be extinct and transferred the reserve lands at Oatscott to British Columbia. ${ }^{139}$ Justice Willcock noted that the

Arrow Lakes Band appears to have been the only Indian band in British Columbia history to have been declared extinct by Canada and have its reserve land revert to the province. However, Sinixt individuals were and are living among and as members of the Osoyoos, Penticton, and Okanagan Bands of the Okanagan Nation Alliance, in Washington State as members of the Lakes Tribe of the Colville Confederacy, and off reservation in Canada and the United States. ${ }^{140}$

The problem for the petitioners was proving the existence of a present-day identifiable claimant group that they represent. Unfortunately, the evidence regarding the continuing existence of a distinct Sinixt people was inconsistent. There were also "competing claims to speak for the contemporary manifestation of the historic rights-bearing group." 141 The Sinixt Nation Society, to which the petitioners belong, was incorporated in 2006 to provide education about the history, culture, and traditions of the Sinixt people in British Columbia and to promote their interests. Counsel for the petitioners nonetheless "acknowledged that the Society cannot claim or enforce an aboriginal right or title and is not entitled to an injunction. Evidence of the existence of the Society and its role is put before the court solely as evidence of the composition of the Sinixt Nation and recognition of the individual named petitioners as representatives of that organization or collective.”142 But the evidence did not disclose clear criteria for

\footnotetext{
139 Ibid. at para. 34 .

${ }^{140}$ Ibid. at para. 42.

141 Ibid. at para. 56.

142 Ibid. at para. 61.
} 
membership in the Society or reveal how individuals become members, nor was its authority to represent the Sinixt as a whole accepted by all interested parties, matters that obviously bothered Justice Willcock. He decided that, in order to have standing to bring a representative action, the petitioners had to "clearly define a distinct aboriginal collective by objective criteria, so that their claim that a collective with rights-bearing attributes exists and their claim to be the appropriate representatives of that collective can be adjudicated upon.” ${ }^{143}$ He found that they had failed to do so, and as a result he dismissed their petition because it had not been properly brought as a representative action. This decision was plainly based on lack of adequate evidence, as Justice Willcock said he would have reserved judgment pending a hearing of an application to produce additional evidence, "if an application had been brought and if there was a prospect that further evidence could address the deficiencies in the representative case." 144 An application to appeal this decision was dismissed by B.C. Court of Appeal as moot because the logging the petitioners were trying to prevent had already been completed by the time the appeal reached that court! ${ }^{145}$

The Campbell case reveals that, in situations where the present-day existence of an Aboriginal collective that holds or claims Aboriginal rights or title is in doubt, the onus is on the Aboriginal claimants to prove both its existence and its connection with the historical community from whom the rights or title are derived. ${ }^{146}$ If the representative capacity of the plaintiffs in

\footnotetext{
143 Ibid. at para. 163.

${ }^{144}$ Ibid. at para. 165. Note that Willcock J.’s judgment contains a lengthy, careful analysis of the law in relation to representative actions involving Aboriginal claims that could assist future litigants in avoiding some of the potential pitfalls in bringing these kinds of actions.

${ }^{145}$ Campbell v. British Columbia (Minister of Forests and Range), 2012 BCCA 274; [2012] 3 C.N.L.R. 6.

146 The evidentiary onus here appears to be similar to the onus where Métis Aboriginal rights are claimed. In Powley, above note 35 at para. 28, the Supreme Court accepted that the trial judge's finding of a contemporary rights-bearing Métis community was "supported by the evidence and must be upheld.” In
} 
an Aboriginal title, rights, or duty to consult case is challenged, as it was by the Minister in Campbell, the decision also suggests that the plaintiffs might have to prove that they have the authority to bring the action on behalf of the present-day collective that holds or claims the title or rights. ${ }^{147}$ However, in our examination of Nlaka'pamux Nation we saw that Justice Sewell took a more generous approach where the duty to consult is concerned, ruling that "the government must discharge its duty to consult by taking reasonable steps to ensure that all points of view within a First Nation are given appropriate consideration", ${ }^{148}$ and this aspect of his decision was upheld by the Court of Appeal. ${ }^{149}$ Significantly, Justice Willcock cited the Court of Appeal's decision in Nlaka'pamux Nation, ${ }^{150}$ without remarking any discrepancy between the flexible approach to representative capacity in that case and his own approach.

In summary, our examination of the duty to consult cases that are most relevant to the identity of Aboriginal rights and title holders or claimants reveals that Canadian courts have not yet established clear guidelines for addressing this issue. However, we know from the Supreme Court's decision in Behn that the duty to consult is owed to the collective

\footnotetext{
Campbell, above note 133 at paras. 114-20, Willcock J. quoted Powley on the issue of membership in the contemporary community, and concluded at para. 120: "These passages suggest that it is not enough that a contemporary community acknowledge an individual's membership in the community in order to establish that individual's status. The contemporary community itself must be able to establish its continuity with the historic rights-bearing community. Recognition of an individual's status by a newly-formed community is not sufficient to confer status upon that individual to claim s.35 rights" [emphasis added]. See also the quotation from Marshall/Bernard, above note 6, accompanying note 38 above, and Labrador Métis Nation v. Newfoundland and Labrador (Minister of Transportation and Works), 2007 NLCA 75, [2008] 1 C.N.L.R. 48 at paras. $46-49$.

${ }^{147}$ See also PF Résolu Canada Inc. c. Wawatie, 2014 QCCS 3972, leave to appeal denied, 2014 QCCA 1840; Manatch v. Louisiana-Pacific Canada Ltd., 2014 QCCS 4350, [2015] 2 C.N.L.R. 261 at paras. 5274.

${ }^{148}$ Nlaka'pamux Nation, above note 130 at para. 73.

${ }^{149}$ NNTC, above note 132.

${ }^{150}$ Campbell, above note 133 at para. 80 .
} 
that holds or asserts the rights or title. ${ }^{151}$ It is therefore necessary to define the contemporary collective, as was held in Campbell ${ }^{152}$ - though how precisely remains to be seen - and show its connection with the pre-contact or pre-sovereignty collective from whom the claimed rights or title are derived. ${ }^{153}$ Also, the organization or individuals who claim that the duty is owed to them as representatives of the rights or title holding collective must have the authority to act in that capacity on behalf of the collective. ${ }^{154}$ In instances where a subgroup within the collective is the custodian or caretaker of the rights or title in question, that subgroup may be able to engage in consultation on behalf of the collective, as Groberman J.A. suggested in the Court of Appeal decision in Tsilhqot'in Nation. ${ }^{155}$ The cases we have examined also reveal that, if unquestioned, the requisite authority is usually assumed from the circumstances, but when challenged it has to be established by evidence. ${ }^{156}$ But the Nlaka'pamux Nation decision suggests that, where there are divisions among the rights or title holders or claimants, the duty to consult may be owed to more than one organization representing different interests within the collective. ${ }^{157}$

\section{Conclusions: From Title and Rights to Governance}

\footnotetext{
${ }^{151}$ See text accompanying note 117 above.

152 See text accompanying note 143 above.

153 The Supreme Court views this as a continuity requirement. See Marshall/Bernard, above note 6 at para. 67: "The requirement of continuity in its most basic sense simply means that claimants must establish they are right holders. Modern-day claimants must establish a connection with the pre-sovereignty group upon whose practices they rely to assert title or claim to a more restricted aboriginal right.”

154 See quotation from Behn accompanying note 117 above.

155 See text accompanying notes 51-52 above.

${ }^{156}$ See discussion of Campbell accompanying notes 141-45 above.

${ }^{157}$ See text accompanying notes 130-32 above. Nlaka'pamux Nation, above note 130, also suggests that, in the case of overlapping claims, a duty to consult may be owed to more than one collective. In some instances, claims of this sort may involve joint Aboriginal title, where the duty to consult would be owed to each collective claiming joint title. On joint title, see McNeil, “Joint Aboriginal Title”, above note 32.
} 
Our examination of relevant case law has revealed that Aboriginal rights and title are communal rights vested in present-day collectives that are connected by descent or succession to the Indigenous people whose practices, customs, and traditions are the source of specific Aboriginal rights, or who were in exclusive occupation of land giving rise to title at the time of Crown assertion of sovereignty. While the specific rights cases discussed in Part 2 do shed some light on the issue of the identity of rights holders, the fact that most of those cases involved prosecution of individuals has meant that precise identification of the rights holding collective was usually unnecessary. The Aboriginal title cases discussed in Part 1 - especially the Tsilhqot'in Nation decision - while less numerous are nonetheless more illuminating because, apart from Marshall/Bernard, they involved civil actions for declarations of title on behalf of Aboriginal collectives. The duty to consult cases discussed in Part 3 are also germane to this discussion, but we have seen that this duty, while owed to rights and title holders or claimants, can be fulfilled by consultation with organizations or individuals that have been authorized by rights or title holders or claimants to represent them. In cases where this authority is not questioned, the precise identity of the proper rights or title holders or claimants themselves is not always apparent.

Our analysis of the trial and Court of Appeal decisions in Tsilhqot'in Nation revealed that the judges engaged directly with the issue of the identity of rights and title holders, and decided that the current holder of Aboriginal rights and title is the Tsilhqot'in Nation as a whole, not Indian Act bands. This conclusion, which does not appear to have been challenged by any of the parties on appeal to the Supreme Court, was implicitly affirmed by the Court's declaration of the Tsilhqot'in Nation's Aboriginal 
title. However, I do not understand this to mean that rights and title will be vested in Aboriginal nations in every instance; instead, it depends on the evidence. At trial in Tsilhqot'in Nation, Justice Vickers stated that the inquiry into the identity of the rights and title holders "is primarily a matter of fact to be determined on the whole of the evidence relating to the specific society or culture." ${ }^{158}$ He found that the "Tsilhqot'in people were the historic community of people sharing language, customs, traditions, historical experience, territory and resources at the time of first contact and at sovereignty assertion." "159 Any rights of individuals or subgroups were derived from the collective actions, traditions, and experience of the Tsilhqot'in Nation. ${ }^{160}$ As for the holders of present-day rights and title, Vickers J. found as a fact that

Tsilhqot'in people make no distinction amongst themselves at the band level as to their individual right to harvest resources. The evidence is that, as between Tsilhqot'in people, any person in the group can hunt or fish anywhere inside Tsilhqot'in territory. The right to harvest resides in the collective Tsilhqot'in community. Individual community members identify as Tsilhqot'in people first, rather than as band members. ${ }^{161}$

So although one Indian Act band, the Xeni Gwet'in, is currently the caretaker or custodian of the Claim Area where Aboriginal rights and title were declared, it is not the rights and title holder. Rights and title are vested in the Tsilhqot'in Nation as a whole. ${ }^{162}$

\footnotetext{
${ }^{158}$ Tsilhqot'in Nation, BCSC, above note 29 at para. 439.

${ }^{159}$ Ibid. at para. 470.

160 Ibid.

${ }^{161}$ Ibid. at para. 459.

${ }^{162}$ See also ibid. at para. 468: “In the modern Tsilhqot'in political structure, Xeni Gwet'in people are viewed amongst Tsilhqot'in people as the caretakers of the lands in and about Xeni, including Tachelach'ed. Other bands are considered to be the caretakers of the lands that surround their reserves. Still, the caretakers have no more rights to the land or the resources than any other Tsilhqot'in person.”
} 
Although an Aboriginal rights rather than a title case (title was claimed but not dealt with), it is worth comparing the decision of Justice Garson in Ahousaht Indian Band with Tsilhqot'in Nation. In the former case, Garson J. decided that the current holders of the Aboriginal right to fish commercially are the five Indian Act bands that are the successor collectives of the five Nuu-chah-nulth Nations whose practices, customs, and traditions gave rise to the right. ${ }^{163}$ In reaching this conclusion, she accepted the plaintiffs' contention that, “[a]fter British Columbia's entry into Confederation in 1871, each of the Nuu-chah-nulth Nations was constituted as a band under the predecessor of the Indian Act, R.S.C. 1985, c.I-5, and, today, each band is the legal representative of its predecessor Nation and the lawful holder of the collective Aboriginal rights and title of that Nation.”164 Her decision that Indian Act bands are the current holders of the fishing right was therefore based on the evidence, as was Justice Vickers' decision in Tsilhqot'in Nation that the Tsilhqot'in Nation as a whole is the holder of Aboriginal rights and title.

Evidence of the identity of the appropriate current holders or claimants of Aboriginal rights and title evidently must come from the Indigenous people concerned. As Justice Groberman stated in his Court of Appeal judgment in Tsilhqot'in Nation, expressing agreement with Justice Vickers, "the definition of the proper rights holder is a matter to be determined primarily from the viewpoint of the Aboriginal collective itself." 165 That viewpoint needs to be demonstrated by evidence. Given that determination of the question of who has rights is at least partly a matter of law, this suggests that Indigenous law is relevant to answer this question.

\footnotetext{
163 See text accompanying notes 98-104 above.

${ }^{164}$ Ahousaht Indian Band, BCSC, above note 71at para. 7.

${ }^{165}$ Tsilhqot'in Nation, BCCA, above note 29 at para. 149.
} 
But because Canadian judges are generally unfamiliar with Indigenous law and cannot access it through conventional legal research, it has to be presented to them mainly through testimony by Indigenous people who are acknowledged in their communities as the authorities on that law.

Once the collective holder of Aboriginal rights or title has been identified, one needs to consider who can exercise those rights or enjoy the benefits of that title, and on what terms. ${ }^{166}$ The kinds of rights involved, whether rights to hunt, fish, occupy and use land, and so on, generally cannot be enjoyed and exercised by a collective as such; instead, they are enjoyed and exercised by individuals, families, and other smaller groups. Given that the collective is necessarily made up of individual members, it is essential to be able to determine who the members are. As Vickers J. observed in Tsilhqot'in Nation, this is an internal matter to be decided by the collective: "Membership is identified by the community. It should always be the particular Aboriginal community that determines its own membership."167

In my opinion, all this leads inevitably to the conclusion that the rights or title holding collective must have governmental authority. ${ }^{168}$

\footnotetext{
${ }^{166}$ See Slattery, “Understanding Aboriginal Rights”, above note 29 at 745: "the rights of individuals and other entities within the group are determined inter se, not by the doctrine of aboriginal title, but by internal rules founded on custom. These rules dictate the extent to which any individual, family, lineage, or other sub-group has rights to possess and use lands and resources vested in the entire group. The rules have a customary base, but they are not for that reason necessarily static. Except to the extent they may be otherwise regulated by statute, they are open to both formal and informal change, in accordance with shifting group attitudes, needs, and practices.” This passage was quoted with apparent approval by both Vickers J. at trial in Tsilhqot'in Nation, BCSC, above note 29 at para. 471, and Groberman J.A. in the B.C.C.A., Tsilhqot'in Nation, BCCA, above note 29 at para. 149.

${ }^{167}$ Tsilhqot'in Nation, BCSC, above note 29 at para. 444.

${ }^{168}$ While not deciding issues of Indigenous governance, Vickers J. appears to have agreed with this assessment. Ibid. at paras. 471-72, he quoted with approval from two articles, cited in note 29 above, where Brian Slattery distinguished between the external and internal aspects of Aboriginal title. Internally, Slattery wrote in 1987, "the rights of group members among themselves ... are governed by rules peculiar to the group, as laid down by custom or internal governmental organs": Slattery, "Understanding Aboriginal Rights", above note 29 at 745 [emphasis added]. In the B.C. Court of Appeal, Groberman J.A. quoted the same passage, again with apparent approval: Tsilhqot'in Nation, BCCA, above note 29 at para.
} 
Governmental structures and powers are obviously necessary for a community to make collective decisions about how its communal rights are to be allocated and managed. ${ }^{169}$ Determinations about membership in the community also involve the exercise of governmental authority. This matter of governance was put before the Supreme Court of Canada in Delgamuukw, but the Court declined to consider it, sending the matter back to trial along with the issue of the existence of Aboriginal title. ${ }^{170}$ But now, with the declaration of collective Aboriginal title in Tsilhqot'in Nation, the matter can no longer be avoided. In the absence of guidance from Canadian courts, Indigenous peoples can take the initiative in exercising their governance authority. In the Tsilhqot'in Nation judgment, the Supreme Court expanded the authority of the provinces over Aboriginal title lands by discarding the application of the doctrine on interjurisdictional immunity in this context. ${ }^{171}$ One reason the Court gave for doing so was to avoid a legal vacuum. ${ }^{172}$ But given that Indigenous peoples have their own laws in relation to their title lands and the exercise of other Aboriginal rights, there is no legal vacuum. ${ }^{173}$ By exercising their governmental authority and ensuring that their laws are respected, Indigenous peoples can "pro-actively use and manage" their title lands, as the Supreme Court in Tsilhqot'in Nation said they have a right to do. $^{174}$

149. See also, John Borrows, "The Durability of Terra Nullius; Tsilhqot'in Nation v British Columbia" (2015) 48 UBC L. Rev. 701, especially 717-20 [Borrows, “Terra Nullius”].

${ }^{169}$ See Campbell v. B.C., above note 32 at para. 137: 'The right to Aboriginal title 'in its full form', including the right for the community to make decisions as to the use of the land and therefore the right to have a political structure for making those decisions, is, I conclude, constitutionally guaranteed by Section 35 [of the Constitution Act, 1982].” See also the other references in note 32 above.

${ }^{170}$ Delgamuukw, SCC, above note 5 at paras. 170-71.

${ }^{171}$ Tsilhqot'in Nation, SCC, above note 7 at paras. 131-52. For critical commentary, see McNeil,

"Aboriginal Title and the Provinces", above note 28.

${ }^{172}$ Tsilhqot'in Nation, SCC, above note 7 at para. 147.

${ }^{173}$ See Napoleon, “Tsilhqot'in Law", above note 1, especially 894-95; Christie, above note 64; Borrows, "Terra Nullius", above note 168 at 738-40.

${ }^{174}$ Tsilhqot'in Nation, SCC, above note 7 at para. 73. 